\title{
The Potential to Secure a Fair Trial Through Evidence Exclusion: A Swiss Perspective
}

\author{
Laura Macula
}

\begin{abstract}
Swiss criminal procedure has a strong inquisitorial tradition and its primary purpose is the search for the "material truth." However, authorities are neither obliged nor allowed to search for this truth at any cost and are limited by procedural rules, which also serve to protect a defendant from the authorities. One possible means of enforcing such procedural rules is the exclusion of improperly obtained evidence. In Switzerland, the legislature established explicit provisions around the collection of evidence and its admissibility in criminal proceedings by adopting art. 139-141 of the Criminal Procedure Code in 2011. This is a comprehensive statutory regulation that is unique in Europe. Nevertheless, the Swiss Supreme Court continues to find ways to preserve its own power over the admission of evidence and often errs on the side of admitting evidence. With a focus on this tension between the legal framework and the jurisprudence of the Supreme Court, the Swiss country report describes the relevant legal framework, phases of the criminal process, and the relevant parties to criminal proceedings. Also discussed in detail are the current regulations as well as the Supreme Court's case law on exclusionary rules. An assessment of the potential for such rules to safeguard individual rights and prevent improper evidence acquisition is a focus of the paper.
\end{abstract}

\section{Introduction}

It was not until 2011 that a unified Swiss criminal procedure code amalgamated the legal framework for criminal trials in the 26 cantons of Switzerland. Bringing together different legal traditions of continental Europe, Swiss criminal procedure is characterized by legal scholars as inquisitorial. This assessment corresponds with a traditional focus on searching for the "material truth" (or, what actually happened) ${ }^{1}$

${ }^{1}$ Schmid, 2017 at $\S 1$ no. 7.

L. Macula (ه)

MLaw, University of Basel, Basel, Switzerland

e-mail: Laura.Macula@unibas.ch

(C) The Author(s) 2019

S. Gless and T. Richter (eds.), Do Exclusionary Rules Ensure a Fair Trial?

Ius Gentium: Comparative Perspectives on Law and Justice 74,

https://doi.org/10.1007/978-3-030-12520-2_2 
as the primary aim of criminal proceedings. ${ }^{2}$ Today, however, the search for truth is neither an absolute goal in the Swiss criminal justice system nor do police, prosecutors, or courts have unlimited powers. ${ }^{3}$ Rather, present-day legislation acknowledges the competing interests of the State and the individuals involved and appreciates a need for them to be balanced on a case-by-case basis via legislation and, more specifically, law enforcement authorities and courts. Accordingly, Swiss criminal proceedings are characterised by formal requirements that seek to ensure a fair trial while also safeguarding individual rights and preventing abuses of power by the authorities. ${ }^{4}$ According to the theory espoused in legal texts, exclusionary rules play an important role in establishing this balance by banning the use of illegally obtained evidence and enforcing limitations in criminal proceedings. ${ }^{5}$ However, the exclusion of evidence also poses a constraint on the establishment of the material truth. ${ }^{6}$ Thus, by defining formal requirements and individual rights in criminal procedure, the legislature determines the cost of finding the material truth $^{7}$-at least in theory.

The first Swiss Criminal Procedure Code (CPC $)^{8}$ explicitly stipulates exclusionary rules in art. 141, which establishes a far-reaching and relatively comprehensive legal regime. ${ }^{9}$ These largely clear-cut rules represent a new approach since they have significantly reduced the amount of judicial discretion allowed relative to the prior cantonal regime. Before the advent of the CPC, the Swiss Supreme Court (SSC) made decisions around the admissibility of evidence by balancing competing interests on a case-by-case basis ${ }^{10}$ and often admitted illegally obtained evidence in pursuit of the material truth. ${ }^{11}$ In a 2007 case (prior to the implementation of the $\mathrm{CPC}$ ), the Court rejected strict exclusion of indirect evidence on the ground that the acquittal of an obviously guilty defendant would be "disturbing" ("stossend"). ${ }^{12}$

\footnotetext{
${ }^{2}$ See e.g., Gless/Martin, 2015 at 164 with further references.

${ }^{3}$ Wohlers in Donatsch et al., 2014 at art. 6 no. 2 with further references.

${ }^{4}$ Keller, 2011 at 231.

${ }^{5}$ Oberholzer, 2012 at no. 695.

${ }^{6}$ Wohlers in Donatsch et al., 2014 at art. 6 no. 2.

${ }^{7}$ Keller, 2011 at 231 et seq.

${ }^{8}$ Schweizerische Strafprozessordnung (StPO), officially translated as Swiss Criminal Procedure Code (CPC) of 5 October 2007 (Status as of 1 October 2016), SR 312.0, available online at $<$ https://www.admin.ch/opc/en/classified-compilation/20052319/index.html>, accessed 22 November 2018.

${ }^{9}$ With exceptions, see below 3.1.3.

${ }^{10}$ Wohlers/Bläsi, 2015 at 160.

${ }^{11}$ Keller, 2011 at 234 with further references; see also below 3.1.3 and 3.2.5.2.

${ }^{12}$ Entscheidungen des Schweizerischen Bundesgerichts (BGE) 133 IV 329, consideration (consid.) 4.5; the decisions of the Swiss Supreme Court are available online at <http://www.bger. $\mathrm{ch} /$ index/juridiction/jurisdiction-inherit-template/jurisdiction-recht.htm>, accessed 22 November 2018.
} 
Even after the CPC was put into place, the Supreme Court has continued to rule in favor of admitting illegally obtained evidence. ${ }^{13}$

With a focus on this tension between the legal framework in the CPC and the jurisprudence of the Swiss Supreme Court, this report seeks to:

- explain the fundamental principles, stages, and actors in Swiss criminal proceedings;

- detail the present regulation in the CPC as well as the Swiss Supreme Court's case law on exclusionary rules;

- assess the potential of those exclusionary rules to safeguard individual rights and to prevent torture and improper compulsion in particular.

\section{Establishing Facts in Swiss Criminal Proceedings}

\subsection{Legal Framework and Relevant Actors}

\subsubsection{General Rules}

Until 2011, Switzerland, a country of approximately eight million inhabitants, had 26 diverse $^{14}$ cantonal criminal procedure codes, three federal codes of military law, ${ }^{15}$ laws around administrative criminal procedure, ${ }^{16}$ and laws around federal criminal procedure. ${ }^{17}$ The different cantonal codes, as well as the Swiss legal system in general, were significantly influenced by the German and the French legal systems due to the various German-speaking and Francophone parts of the country. The Swiss cantonal codes thus embodied diverse components of continental European legal traditions. ${ }^{18}$

This fragmented regulation of criminal procedure necessitated the criminal justice system be flexible enough to accommodate the various legal regimes. The cantonal and federal legislature assured this flexibility by leaving considerable discretion to law enforcement authorities. ${ }^{19}$ The Federal CPC, which came into

\footnotetext{
${ }^{13}$ Schweizerisches Bundesgericht (Swiss Supreme Court, BGer) 6B_684/2012 of 15 May 2013; BGE 138 IV 169; Wohlers/Bläsi, 2015 at 169.

${ }^{14}$ Ruckstuhl et al., 2011 at no. 59.

${ }^{15}$ Militärstrafgesetz of 13 June 1927 (Status as of 1 January 2017), SR 321.0, available online at $<$ https://www.admin.ch/opc/de/classified-compilation/19270018/index.html>, accessed 22 November 2018.

${ }^{16}$ Bundesgesetz über die Bundesstrafrechtspflege of 15 June 1934, SR 312.0, invalidated.

${ }^{17}$ Bundesgesetz über das Verwaltungsstrafrecht of 22 March 1974 (Status as of 1 Oktober 2016), SR 313.0, available online at <https://www.admin.ch/opc/de/classified-compilation/19740066/ index.html>; accessed 22 November 2018.

${ }^{18}$ Gless/Martin, 2015 at 160.

${ }^{19}$ Gless/Martin, 2015 at 160.
} 
effect in January 2011, represents the effort to unify and harmonize all of the different cantonal criminal procedure codes. Its primary goal is not to accommodate different regional traditions, rather it is to create nation-wide consistency in criminal law and procedure, and promote uniform and efficient enforcement of those laws. ${ }^{20}$ Accordingly, the CPC of 2011 established a stricter legal framework compared to the former cantonal procedure codes, and particularly so for exclusionary rules. ${ }^{21}$ Currently, a further reform of selected articles of the CPC is being planned. ${ }^{22}$

\subsubsection{Duties in Criminal Investigations}

Swiss criminal procedure is rooted in the inquisitorial tradition with the primary purpose of searching for the material truth. At least in theory, the proceedings aim to create a "precise reproduction of the historical incidents" 23 and convict and punish defendants only for the acts or omissions for which he or she is responsible. $^{24}$ The inquisitorial principle, explicitly laid out in art. $6 \mathrm{CPC}$, commits all prosecution authorities (police, public prosecution), ${ }^{25}$ as well as the courts ${ }^{26}$ to establish all relevant facts in the assessment of an alleged criminal offense in addition to an evaluation of the accused's personal situation. Different from adversarial systems, authorities in Swiss criminal proceedings act ex officio-regardless of the parties' conduct and requests. ${ }^{27}$ As art. 6 (2) CPC stipulates, the authorities must investigate all circumstances - exculpatory and incriminatorywith equal care, requiring them to keep an open mind throughout the investigation.

If prosecution authorities fail to comply with art. $6 \mathrm{CPC}$, the relevant evidence must be "re-taken" and presented to the appellate court where possible. If this is not feasible, the failure to do so cannot be interpreted to the detriment of the defendant. $^{28}$ On the contrary, the presumption of innocence (art. 10 (1) CPC) and the principle in dubio pro reo ("when in doubt, for the accused," art. 10 (3) CPC) impose the burden of proof on the prosecution. It is their duty not only to investigate, but to prove all circumstances creating criminal liability. This duty is limited by art. 139 (2) CPC, which states that "no evidence shall be led on matters that are irrelevant, obvious, known to the criminal justice authority or already adequately

\footnotetext{
${ }^{20}$ Keller, 2011 at 230.

${ }^{21}$ Gless/Martin, 2015 at 161.

${ }^{22}<$ https://www.bj.admin.ch/bj/de/home/sicherheit/gesetzgebung/aenderungstpo.html>, accessed 22 November 2018.

${ }^{23}$ Keller, 2011 at 230.

${ }^{24}$ Schmid, 2017 at $\S 1$ no. 7.

${ }^{25}$ Spelled out in detail in art. 306 et seq. and 308 et seq. CPC; see below 2.1.3.1 and 2.1.4.

${ }^{26}$ Spelled out in detail in art. $343 \mathrm{CPC}$; see below 2.1.3.1 and 2.1.4.

${ }^{27}$ Art. 6 (1) CPC; Schmid, 2017 at $\S 9$ no. 154.

${ }^{28}$ Wohlers in Donatsch et al., 2014 at art. 6 no. 10 et seq.
} 
proven in law." ${ }^{, 29}$ Where this evidentiary duty cannot be fulfilled or insurmountable doubts as to the defendant's guilt persist, the court must base its decision on the circumstances that are most favorable to the defendant and, where necessary, acquit. ${ }^{30}$ The court, however, has wide discretion in this regard; art. 10 (2) CPC provides that the court shall assess all available evidence in accordance with the opinions it has formed throughout the entire course of the proceedings. Consequently, in Swiss criminal proceedings, there is no ranking order for evidence; as long as all evidence is gathered lawfully, each piece can be relevant. The weight of any one piece of evidence depends on how persuasive the court finds it to be. ${ }^{31}$ Importantly, the court's decision, including the assessment of evidence, has to be objective, transparent and comprehensible. ${ }^{32}$ Indeed, the aim of art. 10 (2) CPC is to avoid the arbitrary assessment of evidence while simultaneously fulfilling the principles of the inquisitorial system. The rationale behind this provision is that judgments are more likely to be based on the material truth if the court is not bound by rigid evidentiary rules and is free to form an opinion based on the entire proceeding. ${ }^{33}$

\subsubsection{Securing a Fair Trial}

The general principle of a fair trial, both in Swiss law and elsewhere, finds its origin in a variety of legal principles. Firstly, it is binding as a general principle of international law imposed by art. 6 (1) of the European Convention on Human Rights (ECHR) ${ }^{34}$ and art. 10 and 14 (1) of the International Covenant on Civil and Political Rights, Part II ${ }^{35}$ (ICCPR II). ${ }^{36}$ Second, it has been expressly codified in Swiss law in art. 29 (1) of the new Federal Constitution of $1999^{37}$ and in art. 3 (2) lit. $\mathrm{c}$ of the new CPC. ${ }^{38}$ Article 3 (2) lit. c CPC explicitly stipulates that all persons involved in criminal proceedings should be treated equally and fairly and should be granted the right to be heard.

\footnotetext{
${ }^{29}$ Gless in Niggli et al., 2014 at art. 139 no. 31; see below 2.1.4.

${ }^{30}$ Pieth, 2016 at 55 et seq.; also BGE 124 IV 88 consid. 2.a.

${ }^{31}$ Schmid, 2017 at $\S 13$ no. 229; Pieth, 2016 at 186.

${ }^{32}$ Pieth, 2016 at 186 with further references.

${ }^{33}$ Schmid, 2017 at $\S 13$ no. 225.

${ }^{34}$ European Convention for the Protection of Human Rights and Fundamental Freedoms of 4 November 1950, available online at <http://www.echr.coe.int/Documents/Convention_ENG.pdf >, accessed 22 November 2018.

${ }^{35}$ Second Optional Protocol to the International Covenant on Civil and Political Rights of 16 December 1966, available online at <http://www.ohchr.org/Documents/ProfessionalInterest/ccpr. pdf $>$, accessed 22 November 2018.

${ }^{36}$ Brun, 2015 at 55 with further references.

${ }^{37}$ Swiss Federal Constitution of 18 April 1999 (Status as of 12 February 2017), SR 101, available online at <https://www.admin.ch/opc/de/classified-compilation/19995395/index.html>, accessed 22 November 2018.

${ }^{38}$ Schmid, 2017 at $\S 6$ no. 95 .
} 
The principle of a fair trial does not ensure that the outcome of the proceedings reflects what actually happened (i.e. the material truth), but it attempts to safeguard the fairness of the procedure itself. Although this may result in the finding of the material truth, that is not always the case. ${ }^{39}$ The concept of a "fair trial" is broad and, as a result, its core meaning can be difficult to grasp..$^{40}$ In practice, however, the principle of a fair trial encompasses a number of specific objectives. It addresses compliance with procedural rules ${ }^{41}$ (which is of particular importance in criminal proceedings $)^{42}$ and requires that the parties to the proceedings be treated as "subjects rather than objects." In other words, the right to a fair trial guarantees that the parties be given the opportunity to influence the proceedings (and, therefore, the outcome), and to be able to effectively exercise their individual rights. The principle can be understood more concretely through the individual procedural rights of the parties, although it represents more than just a summation of those rights. ${ }^{43}$

The individual rights and procedural guarantees that comprise the general principle of a fair trial are detailed in different provisions of the CPC, namely the right to an independent and impartial tribunal (cf. art. $4 \mathrm{CPC}$ ), the right to be heard (cf. art. $107 \mathrm{CPC}$ and 109 et seq. CPC), formal requirements for criminal proceedings (cf. art. 2 CPC), the right to a public (cf. art. 69 (1) CPC) and expeditious proceeding (cf. art. 5 CPC), the presumption of innocence (cf. art. 10 (1) CPC), the right against self-incrimination (art. 113 (1) CPC), the right to be present and participate in the proceedings (cf. art. $147 \mathrm{CPC}$ ), and the right to defense counsel (cf. art. 127 et seq., particularly art. 132 et seq. CPC). The CPC also explicitly prohibits the obtainment of evidence through torture and other methods that violate human dignity (cf. art. 3 (2) lit. d and art. $140 \mathrm{CPC}$ ). ${ }^{44}$ Other aspects of a fair trial include the requirement that the authorities inform parties to the proceeding of their rights (cf. for instance art. 107 (2) and 143 (1) lit. c CPC) and the authorities' duty of care. The duty of care seeks to prevent scenarios where parties lose their rights simply because they are unfamiliar with the law, or are otherwise in a compromised position (see, for instance, the protective measures in art. 149-156 CPC). ${ }^{45}$ Furthermore, art. 6 (2) CPC obliges the prosecution authorities to investigate $e x$ officio, and with equal care, both incriminating and exculpating circumstances related to the criminal act and the accused. The provision itself specifies the principle of a fair trial with regard to the establishment of facts. ${ }^{46}$ The principle of a fair

\footnotetext{
${ }^{39}$ Demko, 2007 at 356 et seq.

${ }^{40}$ Demko, 2007 at 359.

${ }^{41}$ Thommen, 2013 at 301.

${ }^{42}$ Vetterli, 2012 at 451.

${ }^{43}$ Demko, 2007 at 360 et seq. with further references.

${ }^{44}$ Wohlers in Donatsch et al., 2014 at art. 3 no. 22; see in detail 2.1.1.2, 2.1.3.1, 2.1.4., 2.2.2., 3.2.1., 3.2.2.

${ }^{45}$ Schmid, 2017 at $\S 6$ no. 102; also Wohlers in Donatsch et al., 2014 at art. 3 no. 22 and BGE 124 I 185 consid. 3 .

${ }^{46}$ Schmid, 2017 at $\S 6$ no. 99 .
} 
trial is also closely related to the so-called "principle of equality of arms," which states that the defense and the prosecution should have equal means at their disposal to pursue and safeguard their respective interests. ${ }^{47}$ That said, absolute equality is generally not feasible in criminal proceedings, which is why the defendant's opportunity to influence the proceedings is of the utmost importance. ${ }^{48}$

\subsubsection{Balancing Fact-Finding and Individual Rights}

A court must strive to establish the truth to give a just and correct judgment. ${ }^{49}$ This belief has been a cornerstone of the inquisitorial model and is a primary reason that Swiss criminal proceedings place a strong emphasis on the search for the material truth. However, according to current law, authorities are neither obliged nor allowed to search for the truth at any cost. Instead, there are limitations created through procedural rules designed to protect a defendant from the authorities while also preventing abuse of power, arbitrariness, and legal inequality ${ }^{50}$ in an environment that still promotes efficient law enforcement. ${ }^{51}$ Not surprisingly, Swiss scholars argue that criminal proceedings today are only required to lead to the forensic truth. ${ }^{52}$ The forensic truth is the result of a truth-seeking process in which the authorities abide by the formal rules of criminal procedure and seek what may be, depending on the circumstances, a limited version of the material truth. ${ }^{53}$ Thus, a fair criminal judgment is not necessarily based on the material truth, but is the outcome of fair and lawful proceedings. ${ }^{54}$ Nevertheless, it is important to keep in mind that the formal procedural rules are not an end in and of themselves and that complying with them is not a reason to lose sight of the main objective to find the material truth and arrive at a fair and just decision. ${ }^{55}$

Despite the importance of the search for the material truth (reflected in art. $6 \mathrm{CPC}$ ), the Swiss legal framework prioritizes the forensic truth in many ways, especially in its efforts to ensure fair trials. According to art. $159 \mathrm{CPC}$, for instance, an accused can briefly consult a defense attorney before the first police interrogation. The defense attorney is also allowed to attend the interrogations. ${ }^{56}$ This is a big step forward in the protection of procedural rights in criminal trials for

\footnotetext{
${ }^{47}$ Schmid, 2017 at $\S 6$ no. 97.

${ }^{48}$ Wohlers in Donatsch et al., 2014 at art. 3 no. 24.

${ }^{49}$ Keller, 2011 at 231.

${ }^{50}$ Keller, 2011 at 231 et seq.

${ }^{51}$ Keller, 2011 at 232.

${ }^{52}$ Wohlers in Donatsch et al., 2014 at art. 6 no. 2 with further references.

${ }^{53}$ Keller, 2011 at 231 et seq.

${ }^{54}$ See to the tension between material truth and justice Fornito, 2000 at 40 et seq.; Trechsel, 2000 at 6 et seq.

${ }^{55}$ Demko, 2007 at 352 et seq. with further references.

${ }^{56}$ In detail however, there are some enforcement problems, Pieth, 2016 at 96 et seq.
} 
Switzerland; prior to the adoption of the CPC, only a few cantons allowed an accused such rights. ${ }^{57}$ On the other hand, these procedural protections introduce the possibility that an accused will be advised by his or her counsel to remain silent or deny the truth, and may even be coached as to what to say. Naturally, this can hinder the search for the material truth. ${ }^{58}$

It is also the case that the establishment of numerous strict exclusionary rules have placed greater emphasis on the forensic truth. ${ }^{59}$ For example, evidence is to be excluded in cases of incomplete or omitted warnings to the accused informing them of the proceedings against them and their legal rights (similar to the Miranda warning in the US) ${ }^{60}$ denial of an essential defense, ${ }^{61}$ procurement of evidence without regard for all parties' participation rights, ${ }^{62}$ use of coercion to obtain evidence, ${ }^{63}$ or indirect evidence gathered as a result of previously tainted evidence. ${ }^{64}$ Art. 141 (2) CPC addresses evidence obtained through a criminal offense or the violation of so-called "regulations on admissibility" and does not establish a strict exclusionary rule, but stipulates a discretionary approach where the search for evidence and the infringement of the defendant's rights are balanced. ${ }^{65}$ The new CPC has formalized the police's investigative procedures and provides for a right to appeal actions by the police and prosecution. ${ }^{66}$ Additionally, regulations around the use of compulsory measures ${ }^{67}$ (i.e. those that give coercive power to the authorities and restrict individuals' personal freedom in order to secure the establishment of the material truth) still require that the interest in finding the truth is balanced with the individual rights at risk. To achieve this balance, the CPC implemented the use of the proportionality principle, ${ }^{68}$ which requires that a sufficient, respectively strong, suspicion for wrongdoing must exist. ${ }^{69}$ Taken together, all of these aspects of the CPC place limitations on the search for the material, objective truth to safeguard the defendant's right to a fair trial.

Changes to the commitment to searching for the material truth are also related to efficiency. ${ }^{70}$ Resource management and cost saving were of great importance to the

\footnotetext{
${ }^{57}$ Jackson/Summers, 2013 at 127; Bundesblatt 2006 at 1193.

${ }^{58}$ Keller, 2011 at 237.

${ }^{59}$ Keller, 2011 at 246.

${ }^{60}$ Art. 158 (2) CPC; Keller, 2011 at 239.

${ }^{61}$ Art. 131 (3) CPC; Keller, 2011 at 241 et seq.

${ }^{62}$ Art. 147 (4) CPC; Keller, 2011 at 243.

${ }^{63}$ Art. 140 (1) and 141 (1) CPC, see in detail below 3.2.4.

${ }^{64}$ Art. 141 (4) CPC, see in detail below 3.2.5.

${ }^{65}$ See below 3.1.2.3.

${ }^{66}$ Keller, 2011 at 247 et seq.; art. 393 (1) lit. a CPC.

${ }^{67}$ Art. 196 et seq. CPC.

${ }^{68}$ Spelled out for instance by art. 197 (1) lit. c CPC (principle of necessity), and art. 221 (1) CPC (exclusion of custody for minor offences), Pieth, 2016 at 132.

${ }^{69}$ Pieth, 2016 at 132 et seq.

${ }^{70}$ in detail Thommen, 2013 at 249 et seq.
} 
drafters of the CPC. ${ }^{71}$ The underlying rationale of the legislation is that not every investigation can be conducted with the same degree of effort and penal authorities must comply with the demands of efficiency in law enforcement, including the need for quick and effective methods that are also economical. ${ }^{72}$ As a consequence, in modern Swiss criminal procedure there is a strong tendency to utilize summary proceedings. ${ }^{73}$ In fact today, $90-99 \%$ of all cases that go forward conclude with a summary penalty order ("Strafbefehl"), ${ }^{74}$ a decision taken by the public prosecutor in a special procedure. Such penalty orders can be issued without prior criminal investigation, including without even interviewing an accused, and can thus be based on insufficient evidence. ${ }^{75}$ However, in theory, art. 352 (1) CPC requires a confession or an otherwise sufficient establishment of the facts for a summary penalty order to be appropriate. If a defendant does not agree with the "offered" order, he or she has the right to object (or "reject") within ten days. ${ }^{76}$ That said, defendants rarely object, often out of a lack of awareness of their right to do so. ${ }^{77}$ Taken together, all of these issues can make summary penalty orders susceptible to error. This was confirmed by a study on miscarriages of justice, ${ }^{78}$ although it should be noted that a large portion of summary penalty orders involve petty offenses with minor penalties. ${ }^{79}$

Another way in which the law places limitations on the establishment of the material truth in order to promote efficiency is through accelerated proceedings ("abgekürztes Verfahren"). ${ }^{80}$ In these proceedings-arising, for instance, in a complicated financial crime case where facts are difficult to establish - the defendant is allowed to contest the facts and the penalty. The truth then becomes a matter

\footnotetext{
${ }^{71}$ Brun, 2015 at 105.

${ }^{72}$ Keller, 2011 at 232.

${ }^{73}$ Brun, 2015 at 98 et seq.

${ }^{74}$ Pieth, 2016 at 249 and 251 with further references; also Gilliéron/Killias, 2007 at 381 who speak of $76 \%$ according to a study from 2002 and Schweizer, 2013 at 1388 who speaks of $95 \%$.

${ }^{75}$ Keller, 2011 at 249 ; also Gilliéron/Killias, 2007 at 389. However, recent reform efforts plan to introduce the mandatory interrogation of the defendant in some cases, e.g. before issuing a penalty order for over 4 months of imprisonment, see art. 352a of the preliminary draft regarding a reform of the CPC submitted by the Swiss Federal Council in December 2017, available online at <https:// www.bj.admin.ch/dam/data/bj/sicherheit/gesetzgebung/aenderungstpo/vorentw-d.pdf $>, \quad$ accessed 22 November 2018.

${ }^{76}$ However, recent reform efforts plan to extend this period to 20 days in cases where the prosecution did not hand over the penalty order personally, see art. 354 (1ter) of the preliminary draft regarding a reform of the CPC submitted by the Swiss Federal Council in December 2017, available online at <https://www.bj.admin.ch/dam/data/bj/sicherheit/gesetzgebung/aenderungstpo/ vorentw-d.pdf>, accessed 22 November 2018.

${ }^{77}$ Art. 354 et seq. CPC; Gilliéron/Killias, 2007 at 390 et seq.

${ }^{78} 67.5 \%$ of all discovered miscarriages of justice between 1995 and 2004 concerned wrong summary penalty orders, see Gilliéron/Killias, 2007 at 378 et seq.

${ }^{79}$ Gilliéron/Killias, 2007 at 388 et seq.

${ }^{80}$ Art. 358 et seq. CPC; Keller, 2011 at 254.
} 
of negotiation. ${ }^{81}$ Summary proceedings have, therefore, been criticized as adversely affecting the establishment of the material truth and, in turn, legal equality. ${ }^{82}$ Some scholars have even claimed that the quest to establish the material truth becomes an illusion in summary proceedings ${ }^{83}$ and this should be compensated for to justify a proscribed penalty. ${ }^{84}$ The CPC, however, significantly limits procedural safeguards in summary proceedings. ${ }^{85}$

\subsubsection{Establishing the Facts, Procedural Rules, and Stages}

Criminal proceedings are typically initiated by the police at the instruction of the public prosecutor or following observations made by police officers and other authorities. ${ }^{86}$ Preliminary investigations (i.e. securing the crime scene; searching for evidence; interviewing witnesses; stopping, arresting or searching for suspects, etc.) fall within the scope of police duties.

Art. 139 CPC enumerates potential types of evidence:

- testimony provided by witnesses or persons providing information (“Auskunftspersonen");

- reports by experts;

- statements by an accused;

- documents and (judicial) inspections. ${ }^{88}$

Although the police handle preliminary investigations, the public prosecutor may provide instructions because such investigations are part of the preliminary proceedings, which fall under the direction of the prosecution. ${ }^{89}$ After the preliminary investigations conclude, the public prosecutor must assess the evidence and make a decision to either investigate further, file charges, make an offer for a summary penalty order, or stop the proceedings altogether. For each of those decisions, the public prosecutor must have sufficient evidence to establish the necessary facts. ${ }^{90}$

\footnotetext{
${ }^{81}$ Brun, 2015 at 100 et seq. with further references; dissenting as far as fact bargaining is concerned Schwarzenegger in Donatsch et al., 2014 at art. 358 no. 6 et seq. with further references.

${ }^{82}$ Brun, 2015 at 107 et seq.

${ }^{83}$ Thommen, 2013 at $250,309$.

${ }^{84}$ Thommen, 2013 at 292 et seq., which the CPC neglects to do, Thommen, 2013 at 81 (as to the summary penalty order).

${ }^{85}$ Thommen, 2013 at 224 et seq.

${ }^{86}$ Art. 306 (1) CPC.

${ }^{87}$ Art. 306 (2) CPC.

${ }^{88}$ Pieth, 2016 at 187 et seq. with further explanations to the question of whether means of evidence other than those mentioned in the CPC are admissible or not.

${ }^{89}$ Art. 307 (2) CPC.

${ }^{90}$ Schmid, 2017 at $\S 2$ no. 15 ; art. 308 et seq. CPC.
} 
Traditionally, public prosecutors in inquisitorial systems choose to either prosecute a case (and go to trial) or dismiss it altogether. They are required to give written notice of the decision to the parties involved and provide a deadline for the submission of a request for further investigation, ${ }^{91}$ which supposedly satisfies an accused's right to participation (and thus, a fair trial). Today, however, most cases that could be prosecuted (half of which are traffic offences), ${ }^{92}$ conclude with the prosecution issuing a summary penalty order. ${ }^{93}$ These decisions are made without a public hearing $^{94}$ and often without even interviewing the defendant (who, most likely, is not represented by defense counsel). ${ }^{95}$ This does not satisfy the four-eye principle (or its equivalent ${ }^{96}$ and in most cases evidence will never be presented to a court for evaluation and a formal judgement. Only where a party raises an objection to the summary penalty order does an action for additional fact-finding begin. ${ }^{97}$ Where the summary penalty order is accepted, it becomes binding as a final judgment. ${ }^{98}$

Even where a public prosecutor decides to take a case to trial, the deciding judges may not hear all relevant evidence in the main hearing because the principle of immediacy is quite flexible under the CPC. ${ }^{99}$ During public main hearings, which are the centerpiece of the main proceedings, ${ }^{100}$ the court ideally takes and directly examines all evidence relevant to the case (e.g., statements of the parties, documents etc.) to form an opinion. The CPC, however, leaves it to the discretion of the court to decide if direct knowledge of the evidence is necessary to reach a decision. ${ }^{101}$ Apart from direct evidence, the court can make a decision based on an accused's criminal file, which is circulated to all judges involved. ${ }^{102}$ As the CPC states, the court shall only take directly new evidence, supplemental evidence that was previously incomplete, and re-take evidence that was improperly obtained during the preliminary proceedings. ${ }^{103}$ Nevertheless, during the main public

\footnotetext{
${ }^{91}$ Art. 318 (1) CPC.

${ }^{92}$ Riklin, 2016 at 477.

${ }^{93}$ See above 2.1.2. vision of the prosecution, see below 2.1.3.2.

${ }^{97}$ Art. 355 CPC.

${ }^{98}$ Art. 354 (3) CPC.

${ }^{99}$ Art. 343 CPC.

${ }^{100}$ Schmid, 2017 at $\S 2$ no. 18.

${ }^{101}$ Critical Pieth, 2016 at 51 et seq.; art. 343 (3) CPC.

${ }^{102}$ Art. 330 (2) CPC; critical Pieth, 2016 at 51 et seq.

${ }^{103}$ Art. 343 (1 and 2) CPC.
}

${ }^{94}$ Pieth, 2016 at 218; critical Brun, 2015 at 98 et seq.; Riklin, 2016 at 493 et seq.

${ }^{95}$ Gilliéron/Killias, 2007 at 394 et seq. However, recent reform efforts plan to introduce the mandatory interrogation of the defendant in some cases, e.g. before issuing a penalty order for over 4 months of imprisonment, see art. 352a of the preliminary draft regarding a reform of the CPC submitted by the Swiss Federal Council in December 2017, available online at <https://www.bj.admin.ch/dam/data/bj/ sicherheit/gesetzgebung/aenderungstpo/vorentw-d.pdf>, accessed 22 November 2018.

${ }^{96}$ Riklin, 2016 at 495 who is critical of the fact that the prosecution is the sole issuing authority, acting without participation of an independent court. As to the problems concerning the super- 
hearing the accused is always questioned directly by the judge overseeing the proceedings. 104

After the main hearing and the presentation of all relevant evidence before the court, the evidence is considered in accordance with the opinions the court has formed throughout the entire course of the proceedings ${ }^{105}$ and a decision to either convict or acquit the accused is made. The judgment is first pronounced orally to the parties with a short explanation (unless the parties waive their right to have the judgment issued publicly) and is later handed down in writing. ${ }^{106}$ Where an appeal is filed against the court of first instance, the appellate court generally bases its decision on the evidence already documented in the criminal file. As a result, the appellate court does not directly take evidence. ${ }^{107}$

In all procedural stages, exclusionary rules are formally binding on authorities. ${ }^{108}$ However, according to the jurisprudence of the Swiss Supreme Court, it is the judge of fact who has the power to enforce exclusionary rules, and who also decides the outcome of a case. ${ }^{109}$

\subsubsection{Establishing the Facts: Actors and Accountability}

\subsubsection{Primary Actors}

The main actors involved in establishing the facts of a criminal case are the police, prosecution and judges. The accused and his or her defense counsel have a limited role in influencing the fact-finding process. Those that do play a role in fact-finding have different interests and views around what the search for truth should look like. On the one hand, police and prosecutors aim to establish the material truth. Their actions must be efficient and consistent with the principles of urgency, economy and effectiveness. ${ }^{110}$ To them, extensive formal requirements around evidence gathering, participation rights, and exclusionary rules are a hindrance to the search for the material truth. ${ }^{111}$ The Supreme Court also appears to fall on the side of pursuing the material truth, particularly in cases where it clearly went to great lengths to admit and consider illegally obtained evidence. ${ }^{112}$ On the other hand, the defense is typically in favor of rigid, formal rules around the taking of evidence, as well as extensive participation rights, and strict exclusionary rules in case of violations. They do not

\footnotetext{
${ }^{104}$ Art. 241 (3) CPC.

${ }^{105}$ Art. 10 (2) CPC.

${ }^{106}$ Art. 351 (3) and art. 84 (1-3) CPC.

${ }^{107}$ Schmid, 2017 at $\S 16$ no. 308; also art. 389 (1) CPC.

${ }^{108}$ Gless in Niggli et al., 2014 at art. 141 no. 35.

${ }^{109} \mathrm{See}$ below 3.1.4.

${ }^{110}$ Keller, 2011 at 232.

${ }^{111}$ Keller, 2011 at 233 et seq.

${ }^{112}$ Keller, 2011 at 234, see also below 3.1.3, 3.2.4.2, 3.2.5.2.
} 
necessarily have an incentive to find the material truth and instead tend to look for a version of the facts that is the most favorable to the defendant. ${ }^{113}$

In some cantonal procedure codes, the police were traditionally tasked with making only the first (and urgent) inquiries autonomously. In practice, however, they did much more. ${ }^{114}$ The new Swiss CPC explicitly states that the police are to establish facts relevant to the criminal offense in question. ${ }^{115}$ The police can autonomously take any evidence; search for, observe, and arrest suspects; and, in emergency cases, search persons and seize property. ${ }^{116}$ Only in the case of severe criminal offenses and other serious matters are the police obliged to immediately inform the prosecution. ${ }^{117}$ Typically, they procure all necessary evidence independently and prepare the entire criminal file (thereby concluding the preliminary investigation) for the prosecution. ${ }^{118}$ Additionally, summary penalty orders and potential judgments are often based entirely on police reports. ${ }^{119}$ Thus, the police play a significant role during preliminary proceedings. This can lead to problems, as individual procedural rights may be circumvented at this less formalized stage of the proceedings, ${ }^{120}$ a stage where the defendant is rarely interviewed or represented by counsel. ${ }^{121}$

The prosecution occupies a powerful place in criminal proceedings in both statutory text and practical application. The new CPC conferred a number of duties and powers upon the prosecution; they are tasked with consistently applying the duty to prosecute, conducting the preliminary proceedings, pursuing criminal offenses within the scope of an investigation, bringing charges, and obtaining favorable plea agreements. ${ }^{122}$ Furthermore, the prosecution can also discontinue criminal proceedings ${ }^{123}$ or chose to issue a summary penalty order, which carries up to six months' imprisonment. ${ }^{124}$ These powers, in addition to others, lead to a concentration of authority within the prosecution, who, in fact, act as lead investigator, judge, and

\footnotetext{
${ }^{113}$ Keller, 2011 at 233.

${ }^{114}$ Pieth, 2016 at 67 et seq.

${ }^{115}$ Art. 306 (1 and 2) CPC.

${ }^{116}$ Pieth, 2016 at 68 et seq.

${ }^{117}$ Art. 307 (1) CPC.

${ }^{118}$ Art. 307 (3) CPC.

${ }^{119}$ Gilliéron/Killias, 2007 at 383 with further references. However, recent reform efforts plan to introduce the mandatory interrogation of the defendant in some cases, e.g. before issuing a penalty order for over 4 months of imprisonment, see art. 352a of the preliminary draft regarding a reform of the CPC submitted by the Swiss Federal Council in December 2017, available online at <https:// www.bj.admin.ch/dam/data/bj/sicherheit/gesetzgebung/aenderungstpo/vorentw-d.pdf $>, \quad$ accessed 22 November 2018.

${ }^{120}$ Pieth, 2016 at 68.

${ }^{121}$ Gilliéron/Killias, 2007 at 394 et seq.

${ }^{122}$ Art. 16 (1 and 2) CPC.

${ }^{123}$ Art. 310,319 et seq. CPC.

${ }^{124}$ Art. 352 (1) CPC.
} 
prosecutor. While this may be efficient, it can compromise the accused's right to an impartial judgment. ${ }^{125}$

Despite the powerful positions occupied by the police and prosecution in criminal investigations, the CPC does set limits in an effort to protect individual rights that fall within the scope of art. 5 (3) ECHR and art. 6 ECHR, including the right to an impartial judgment. The CPC also reserves certain powers for judicial authorities. For example, compulsory measures affecting the personal freedoms of a defendant or third party in a serious way (e.g., custody, preventive detention, bank account monitoring, mass DNA tests, surveillance of post and telecommunications, surveillance using technical devices and undercover investigations) cannot be applied without consent of a special "compulsory measures court" (Zwangsmassnahmengericht). ${ }^{126}$ Furthermore, in all matters that exceed the authority of the prosecution to issue summary penalty orders, the prosecution merely provides the charges while the courts of first instance and the appellate courts decide the substantive issues of the case. ${ }^{127}$ It remains, however, that where summary penalty orders can be issued, a defendant retains the right to object and to ask for a court trial reviewing the punishment order. ${ }^{128}$

The CPC grants full participation rights to the accused with particular attention paid to the right to be heard, including the right to counsel prior to the first police interrogation, the right to access the case file, and the right to request that evidence be taken. ${ }^{129}$ These rights are unfortunately not strictly enforced in practice, ${ }^{130}$ which weakens the role of the accused and the ability of the defense to influence the proceedings. If the defense seeks to exclude a piece of evidence, he or she must submit a removal request to the person overseeing the proceedings. ${ }^{131}$ This is also the case in proceedings before the compulsory measures court. Where the request is rejected, the defense can file an appeal with the court of second instance and, if necessary, the Swiss Supreme Court. ${ }^{132}$

\subsubsection{Supervision of Judicial Authorities and Legal Remedies}

Swiss law only partially regulates the supervision of prosecution authorities; it is, therefore, up to the cantons to decide how to "guard the guardians." Supervision of

\footnotetext{
${ }^{125}$ Pieth, 2016 at 70 et seq.

${ }^{126}$ Custody, preventive detention and bank account monitoring can only be ordered by the court; the other measures simply need an approval by the court; Pieth, 2016 at 73 with further references.

${ }^{127}$ Schmid, 2017 at $\S 3$ no. 18 et seq.

${ }^{128}$ Art. 354 et seq. CPC.

${ }^{129}$ Pieth, 2016 at 57 et seq.

${ }^{130}$ See below 2.1.4.

131"Verfahrensleitung", in the official English translation of the CPC the "director of the proceedings".

${ }^{132}$ See generally Wohlers/Bläsi, 2015 at 173 et seq.
} 
police in routine operations is also under the auspices of cantonal law. ${ }^{133}$ Cases of alleged police misconduct can be reported to the supervisory authority ${ }^{134}$ and, where the suspicion that a crime occurred can be substantiated, police will be prosecuted.

The prosecution also exercises control over the police when conducting criminal investigations. It may instruct the police in a particular way or take control of the proceedings at any time. ${ }^{135}$ Nevertheless, in practice it is difficult for prosecutorial authorities to adequately supervise police work because the CPC does not provide efficient tools to do so. ${ }^{136}$ It is clear, however, that if prosecution authorities observe a police officer improperly eliciting a confession, the officer must be reported to the appropriate authorities. ${ }^{137}$ In order to enable the prosecution and the courts to consider whether evidence has been obtained improperly, the police are obliged to continually record their findings and the means by which they have gathered evidence in a written report provided to the prosecution. ${ }^{138}$ If evidence has been obtained improperly, the public prosecutor will re-take it personally or instruct the police to do so. ${ }^{139}$ The defendant may also submit an application requesting that the official(s) in question be recused from future proceedings. ${ }^{140}$ If the case goes to court, the judges must examine whether the evidence was obtained improperly. Where the court decides to exclude certain evidence, it must re-take it. ${ }^{141}$ Theoretically, in doing this, the courts control not only the final result of the investigation, but also the police and the prosecution.

The supervision of the prosecution is regulated by cantonal law and varies widely across Switzerland. Many questions remain unanswered due to the fragmentary character of the cantonal regulations. ${ }^{142}$ The supervision of judicial authorities, like the prosecution, is difficult because the supervisory body is generally not authorized to intervene in cases; rather its role is limited to administrative and technical supervision. There is one exception in the case of significant violations of the law, ${ }^{143}$ such as police abuse or the improper use of compulsory measures. Additionally, certain cantons have a Chief Public Prosecutor's Office that has the authority to issue instructions on a case-by-case basis. ${ }^{144}$ Supervisory bodies

\footnotetext{
${ }^{133}$ Depending on the canton, the supervisory authority is the superordinate department or the cantonal governing council; see Künzli et al., 2014 at 26.

${ }^{134}$ See Künzli et al., 2014 at 26 et seq.

${ }^{135}$ Art. 307 (2), 312 CPC.

${ }^{136}$ Ruckstuhl et al., 2011 at no. 62; as to the possible legal remedies for misconduct by police see Künzli et al., 2014 at 19 et seq. in detail.

${ }^{137}$ Pursuant to art. 302 CPC, Committee Against Torture (CAT) Report, 2016 at 2.

${ }^{138}$ Art. 307 (3) CPC.

${ }^{139}$ Art. 308 (1), art. 311 (1), art. 312 (1) CPC.

${ }^{140}$ Art. 56 et seq. CPC; CAT Report, 2016 at 1.

${ }^{141}$ BGer 6B_690/2015 of 25 November 2015, consid. 3.4.; art. 343 (2) CPC.

${ }^{142}$ Schweizer, 2013 at 1381 et seq.

${ }^{143}$ Schweizer, 2013 at 1381.

${ }^{144}$ Schweizer, 2013 at 1381.
} 
can also initiate an administrative investigation into alleged misconduct of individual officials and determine the appropriateness of disciplinary measures where necessary. ${ }^{145}$ Overall, there is a risk that prosecutorial authorities will remain largely unsupervised, especially in cantons where the supervision is conducted by executive authorities with limited judicial expertise. ${ }^{146}$

The courts, as judicial authorities, also have supervisory powers, but they are limited to administrative and technical aspects unless there is a severe violation of the law. Aside from that, the errors of judicial authorities can only be challenged through legal remedies. ${ }^{147}$ Accordingly, a defendant has the right to appeal decisions, lodge complaints against the police and the prosecution, ${ }^{148}$ and appeal final judgments. ${ }^{149}$ Where the cantonal remedies have been exhausted, a defendant may appeal to the Swiss Supreme Court. ${ }^{150}$ However, according to the case law on this matter, it is not possible for a defendant to ask that his or her request for an assessment of allegedly illegally obtained evidence (and its potential exclusion) be completed before the court has received the evidence. ${ }^{151}$ This is particularly problematic as the court deciding the admissibility of the evidence will have already seen it and is also the court deciding the substantive matters of the case.

\subsubsection{Liability of the State and Legal Officials for Improper Compulsion in Criminal Investigations}

Apart from accountability in a disciplinary proceeding, an official that has improperly used compulsory measures against a defendant (for example, during an interrogation) is also subject to criminal liability. In such a case, the defendant may report the offense directly to the prosecution. ${ }^{152} \mathrm{He}$ or she may also request compensation for damages, including mental suffering. Such claims following alleged misconduct by officials are subject to cantonal law. That said, all cantons have adopted the concept of exclusive state liability for such claims. Accordingly, they

\footnotetext{
${ }^{145}$ Schweizer, 2013 at 1383 with further references; as to disciplinary measures against police officers in particular, see Künzli et al., 2014 at 57 et seq.; see also CAT Report, 2016 at 3.

${ }^{146}$ Schweizer, 2013 at 1389.

${ }^{147}$ Schweizer, 2013 at 1384.

${ }^{148}$ Art. 393 (1) lit. a CPC. However, this possibility is of little practical relevance so far; Künzli et al., 2014 at 65 et seq.; see also Gless in Niggli et al., 2014 at art. 140 no. 74.

${ }^{149}$ Art. 398 (1) CPC.

${ }^{150}$ Art. 80 (1) Bundesgesetz über das Bundesgericht (BGG) of 17 June 2005 (Status as of 1 January 2017), SR 173.110, available online at <https://www.admin.ch/opc/de/classifiedcompilation/20010204/index.html>, accessed 22 November 2018.

${ }^{151}$ See below 3.1.4.

${ }^{152}$ Pursuant to art. 301 CPC; CAT Report, 2016 at 1 et seq.; as to criminal liability of police officers in detail see Künzli et al., 2014 at 32 et seq.
} 
may only be brought against the state, not the individual official. ${ }^{153}$ Along the same lines, several cantons have created specific procedures for dealing with cases of criminal complaints alleging police misconduct. This involves a hearing conducted exclusively by representatives of the prosecution, police officers from outside the unit in question, or officers from a special police corps addressing such matters. ${ }^{154}$ In addition to these procedures, many cantons and respective municipalities provide for alternative mechanisms of dispute resolution, such as a mediator bureau and/or ombudsman. ${ }^{155}$

\subsubsection{Establishing the Facts: Institutional Safeguards}

In Swiss criminal investigations various institutional safeguards are in place to ensure the objectivity of investigative authorities and the transparency of proceedings. First, art. 6 (2) $\mathrm{CPC}^{156}$ stipulates that authorities must investigate all circumstances - exculpatory and incriminatory — with equal care. Second, art. 3 (2) lit. c and 107 CPC codify the right to be heard, which preserves important participation rights such as access to the criminal file, the opportunity to take part in procedural activities, the right to counsel, the right to comment on the facts and proceedings, and the right to request that further evidence be taken. ${ }^{157}$ The right to be heard also includes the right to be informed about the charge(s) as well as one's own rights. ${ }^{158}$ All of these aspects are institutional safeguards that allow the parties to influence the fact-finding process through participation should they wish to do so. ${ }^{159}$ Hence, the "truth" is not only constructed by the prosecution authorities, but also the defense, each of whom enter into this "open process" with their own biases. In an effort to promote objectivity, art. 141 (5) CPC mandates that authorities keep an open, unbiased view of the case even where illegally obtained evidence incriminating the defendant exists. The provision states that records of inadmissible evidence shall be removed from the criminal files, kept separately until a final judgment has been reached, and then destroyed.

In addition to the principles and rights explicitly granted in the $\mathrm{CPC}$, the code also provides for some degree of flexibility in certain provisions, which has led to a more lenient application of the legal framework around individual rights. Using the example of participation rights, the following three issues have arisen: First,

\footnotetext{
${ }^{153}$ Künzli et al., 2014 at 70 et seq. Thus, those claims cannot be asserted directly in the criminal proceedings against the official either which is incorrectly stated in CAT Report, 2016 at 3.

${ }^{154}$ Zürich, Vaud, Basel-Stadt, Basel-Land, Zug, Bern, Luzern, Sankt-Gallen, Rapperswil-Jona, Wallisellen, Winterthur; see CAT Report, 2016 at 2.

${ }^{155}$ CAT Report, 2016 at 2; also Künzli et al., 2014 at 28 et seq.

${ }^{156}$ See above 2.1.1.1.

${ }^{157}$ Art. 107 (1) CPC. All of these rights are spelled out in detail in other provisions of the CPC.

${ }^{158}$ Pieth, 2016 at 57 et seq.

${ }^{159}$ Demko, 2007 at 360.
} 
according to the Supreme Court's jurisprudence, the prosecution and the court hearing the case may reject the defense's request that further evidence be taken (Beweisantrag) by providing a brief reasoning as soon as the competent body is convinced that no further evidence is needed to decide the case (subject to a review for arbitrariness). ${ }^{160}$ The defendant has no formal remedy, but can submit a new request for additional evidence during the preparation of the main hearing and again during the main hearing. ${ }^{161}$ Second, the defense's access to the file can be suspended until the first interrogation of the accused has taken place and other important evidence has been taken. ${ }^{162}$ Therefore, up to that point, the case file is built upon facts only from the police perspective. Third, in cases of summary penalty orders, the defendant often does not participate in the proceedings at all ${ }^{163}$; instead he or she receives a sentencing offer by mail without a hearing and without the assistance of a defense lawyer. ${ }^{164}$ The prosecution's "offer" frequently is difficult for a layperson to understand ${ }^{165}$ and only in a few specific cases does it provide a rationale (albeit brief) for the decision. ${ }^{166}$ The summary penalty order is thus criticized as problematic for many reasons ${ }^{167}$ and is deemed compatible with art. 6 ECHR only because a defendant theoretically ${ }^{168}$ has the option to reject the "offer" and request a trial. ${ }^{169}$

${ }^{160}$ This is called "anticipated assessment of evidence" (antizipierte Beweiswürdigung), BGE 134 I 140, consid. 5.3. et seq. with further references; also art. 139 (2) and art. 318 (2) CPC as well as Bundesblatt 2006 at 1182; critical Pieth, 2016 at 44, 108 et seq. and 188 et seq. with further references; see also Gless in Niggli et al., 2014 at art. 139 no. 48 et seq., stating that apart from art. 318 (2) CPC requests for additional evidence cannot be rejected due to anticipated assessment of evidence.

${ }^{161}$ Art. 318 (2) CPC; art. 331 (2 and 3) CPC.

${ }^{162}$ Art. 101 (1) CPC; critical Pieth, 2016 at 93 et seq.

${ }^{163}$ Schweizer, 2013 at 1388.

${ }^{164}$ Gilliéron/Killias, 2007 at 394 et seq. However, recent reform efforts plan to introduce the mandatory interrogation of the defendant in some cases, e.g. before issuing a penalty order for over 4 months of imprisonment, see art. 352a of the preliminary draft regarding a reform of the CPC submitted by the Swiss Federal Council in December 2017, available online at $<$ https://www.bj. admin.ch/dam/data/bj/sicherheit/gesetzgebung/aenderungstpo/vorentw-d.pdf $>$, accessed 22 November 2018.

${ }^{165}$ And thus, only rarely "rejected", Riklin, 2016 at 486 et seq.; Gilliéron/Killias, 2007 at 390 et seq.

${ }^{166}$ Riklin, 2016 at 485; Thommen, 2013 at 94 et seq.

${ }^{167}$ See the enumeration in Riklin, 2016 at 495 et seq.; see also the references on critical scholars in Schweizer, 2013 at $1387 \mathrm{fn} .84$.

${ }^{168}$ Only in $5 \%$ of the cases does the summary penalty order not become a legally binding judgment, but the case will go to court, see Schweizer, 2013 at 1380.

${ }^{169}$ Gilliéron/Killias, 2007 at 383 et seq. and 390 et seq.; critical Riklin, 2016 at 485. 


\subsection{Relevance of the Truth and Individual Rights in Criminal Trials}

\subsubsection{Public Interest in Determining the Truth}

In continental Europe, the public traditionally expects the truth to be established following a criminal trial. Due to widespread interest in criminal proceedings, prosecution authorities are under considerable public pressure to establish the truth ${ }^{170}$ and prosecute, particularly in high-profile cases. In contrast, the idea that the alleged perpetrator has human rights that could potentially restrict the search for truth receives little public support. ${ }^{171}$ This is also reflected in the skeptical, and sometimes disapproving, portrayal of criminal procedures in the media, especially where relevant evidence is excluded. This can be observed in even the most well-reputed Swiss newspapers, such as the NZZ (Neue Zürcher Zeitung). For example, in a case where a defendant was acquitted after illegally obtained evidence was excluded, the NZZ reported that the accused was "profiting" from faulty procedure. ${ }^{172}$ The public emphasis on the importance of finding the truth is also illustrated by the growing discontent with public prosecutors "acting like judges" and routinely issuing summary penalty orders without the scrutiny of a formal, transparent procedure. The same goes for accelerated proceedings (a form of negotiated justice ${ }^{173}$ ) which carry with them an elevated risk of a miscarriage of justice given that a defendant might confess solely to ensure a particular outcome. ${ }^{174}$

\subsubsection{Presenting the "Truth" to the Public}

In Switzerland, the fact-finding process prior to a trial is not public ${ }^{175}$ and the investigative work and its results are not officially published by the authorities. Instead, information is published by the media, which tend to be motivated by sensationalist news and are often inadequately informed.

\footnotetext{
${ }^{170}$ Thommen/Samadi, 2016 at 84.

${ }^{171}$ Vetterli, 2012 at 450.

${ }^{172}$ NZZ online 5 August 2002, Ausschlaggebender Beweis darf nicht verwertet werden. Freispruch für Polizisten trotz Tatverdacht, available online at $<$ https://www.nzz.ch/article8BGKE-1.414015>, accessed 22 November 2018.

${ }^{173}$ For both NZZ online 19 April 2013, Immer mehr Strafbefehle. Der Staatsanwalt als Richter, available online at $<$ https://www.nzz.ch/zuerich/der-staatsanwalt-als-richter-1.18067194?reduced= true>, accessed 22 November 2018; also Brun, 2015 at 99 et seq. with further references.

${ }^{174}$ NZZ 29 March 2016 at 9, Deals in Strafverfahren häufen sich. Kritiker befürchten, dass Beschuldigte unter Druck falsche Geständnisse ablegen.

${ }^{175}$ Art. 69 (3) lit. a CPC; Schmid, 2017 at $§ 15$ no. 265.
} 
With few exceptions, the main hearings and the presentation of evidence before courts of first instance ${ }^{176}$ (and the Swiss Supreme Court ${ }^{177}$ ) are public. Court proceedings on compulsory measures, such as rulings on search warrants, preventative detention, or remand are not public. ${ }^{178}$ However, judgments rendered by the courts of first and second instance, ${ }^{179}$ as well as the Supreme Court, ${ }^{180}$ are open to the public. Since April 2016, the Supreme Court has also made publicly available short video recordings of select proceedings. ${ }^{181}$

\subsubsection{Miscarriages of Justice}

A study on miscarriages of justice in Switzerland found that during the period between 1995 and 2004, 237 judgments had been set aside by cantonal courts in retrial proceedings. At first sight, this does not seem to be a large number when compared to the tens of thousands of judgments handed down each year but, given that the requirements for a retrial are very strict, the actual number of miscarriages of justice is likely several times higher. ${ }^{182}$ In almost all of these cases, the contested judgment was decided in favor of the defendant. ${ }^{183}$ It is also noteworthy that $67.5 \%$ of those cases concerned summary penalty orders which, as previously mentioned, are particularly prone to error. ${ }^{184}$ This is due to the fact that summary penalty orders are issued after only a cursory examination of the facts. ${ }^{185}$ Given the nature of this

${ }^{176}$ Art. 69 (1) CPC; art. 30 (3) Swiss Federal Constitution; art. 6 (1) ECHR and art. 14 (1) ICCPR II. The exceptions (for example for the proceedings of second instance and in case of prevailing interest in secrecy) are mentioned in art. 69 (3) and art. 70 CPC as well as in other particular provisions, Schmid, 2017 at $\S 15$ no. 260 et seq.

${ }^{177}$ Art. 59 (1 and 2) BGG.

${ }^{178}$ Art. 69 (3) lit. b CPC.

${ }^{179}$ Art. 69 (1) CPC; Schmid, 2017 at $\S 15$ no. 261. In case the defendant waived the right to the public pronouncement of the judgment or in case of a summary penalty order, the decisions are open for public inspection.

${ }^{180}$ Art. 27 (1) BGG; art. 59 (3) BGG.

${ }^{181}$ Media Release of the Swiss Supreme Court: „Filmaufnahmen zu öffentlichen Urteilsberatungen " of 27 April 2016, available online at <https://www.bger.ch/files/live/sites/ bger/files/pdf/de/11.5.2_15.0.0.3_01_2016_yyyy_mm_dd_T_d_14_41_15.pdf>, accessed 22 November 2018.

${ }^{182}$ Gilliéron/Killias, 2007 at 387.

${ }^{183}$ Gilliéron/Killias, 2007 at 388.

${ }^{184} \mathrm{See}$ Gilliéron/Killias, 2007 at 388 et seq.

${ }^{185}$ Gilliéron/Killias, 2007 at 389; see above 2.2. However, recent reform efforts plan to introduce the mandatory interrogation of the defendant in some cases, e.g. before issuing a penalty order for over 4 months of imprisonment, see art. 352a of the preliminary draft regarding a reform of the CPC submitted by the Swiss Federal Council in December 2017, available online at $<$ https://www. bj.admin.ch/dam/data/bj/sicherheit/gesetzgebung/aenderungstpo/vorentw-d.pdf $>, \quad$ accessed 22 November 2018. 
approach, it is also likely that exclusionary rules are applied perfunctorily and the reliability of the evidence is, therefore, diminished.

\section{Limitations of Fact-Finding with Exclusionary Rules in Switzerland}

\subsection{Exclusionary Rules in Swiss Criminal Proceedings}

\subsubsection{Rationale}

As the primary aim of criminal proceedings is to establish the truth, exclusionary rules require special justification. ${ }^{186}$ The rationale behind exclusionary rules $^{187}$ is not clearly established in Swiss legal literature and case law. Three primary justifications have been proffered: to safeguard procedural rules (including individual rights), to establish the material truth, and to discipline prosecution authorities.

Some see the primary rationale behind exclusionary rules as a guarantee that criminal procedure conforms with the rule of law and that authorities do not infringe upon individual rights, which are more important than the search for the truth. ${ }^{188}$ This is of particular significance in criminal proceedings due to the gravity of the possible sentences. ${ }^{189}$ The exclusion of illegally obtained evidence is thus understood as a safeguard for the accused's rights and a means of preserving the presumption of innocence. ${ }^{190}$ Indeed, the Supreme Court has stated that the accused's right to a fair trial includes the exclusion of unlawfully collected evidence. ${ }^{191}$ In a 1994 decision, the Supreme Court emphasized that after evidence has been illegally collected, the only way to honor the human rights of the accused is to ensure that such evidence is not used against him or her. ${ }^{192}$

The justification for the argument that exclusionary rules ensure the reliability of evidence primarily refers to evidence obtained through torture or other improper force. Because such evidence is deemed unreliable due to coercion, exclusionary rules are seen as necessary to protect the fact-finding process. Therefore, it is argued that the establishment and enforcement of exclusionary rules can optimize the ascertainment of truth in criminal proceedings. ${ }^{193}$ In cases where the witness or

\footnotetext{
${ }^{186}$ Gless in Niggli et al., 2014 at art. 139 no. 23.

${ }^{187} \mathrm{See}$ in detail Fornito, 2000 at 51 et seq.

${ }^{188}$ For more on this double purpose, see Wohlers/Bläsi, 2015 at 159 with further references.

${ }^{189}$ Groner, 2011 at 135.

${ }^{190} \mathrm{Gless} / \mathrm{Martin}, 2015$ at 163.

${ }^{191}$ BGE 131 I 272, consid. 3.2.1; also Gless/Martin, 2015 at 162 et seq. with further references.

${ }^{192}$ BGE 120 Ia 314, consid. 2.c.

${ }^{193}$ In detail Ruckstuhl, 2006 at 20 et seq.; also Gless/Martin, 2015 at 163; Gless in Niggli et al., 2014 at art. 141 no. 6 .
} 
suspect has not been under duress, the exclusion of evidence is more likely to hinder the search for the material truth. ${ }^{194}$

The disciplinary component of exclusionary rules refers to the potential deterrent effect they have upon misconduct by prosecution authorities, and in particular, police officers. While in the United States this is considered to be the primary goal of exclusionary rules, the same rationale is subject to controversial debate in Switzerland. ${ }^{195}$ Some Swiss scholars reject the general applicability of this approach because the concept of disciplining prosecution authorities does not fit into the inquisitorial Swiss system where the prosecution authorities are legally obliged to gather both incriminatory and exculpatory evidence ${ }^{196}$ and are not a party to the criminal proceedings. ${ }^{197}$ However, the dominant opinion in Swiss scholarship maintains that one of the primary purposes of exclusionary rules is to render human rights violations by law enforcement unnecessary since the resulting evidence cannot be used. Thus, according to this line of reasoning, exclusionary rules also have the secondary effect of disciplining prosecution authorities. ${ }^{198}$ Since this view emphasizes the preventive rather than punitive element of exclusionary rules, its proponents argue that it is compatible with the inquisitorial Swiss criminal procedure system. ${ }^{199}$ In fact, this aspect of exclusionary rules (disciplinary measures for prosecution authorities) is one reason they are said to safeguard human rights. Therefore, one could argue that, at least with respect to the use of torture and the use of unauthorized compulsory techniques by prosecution authorities, exclusionary rules can help to (1) enforce human rights by discouraging authorities from violating human rights or by removing from trial any evidence gained in violation of human rights, and (2) establish the material truth.

\subsubsection{The CPC's System of Exclusionary Rules}

As noted above, exclusionary rules place procedural limitations on the fact-finding process. ${ }^{200}$ In Switzerland, the legislature established comprehensive, explicit provisions on the taking of evidence and its admissibility in criminal proceedings

\footnotetext{
${ }^{194}$ Schlauri, 2003 at 100; but see Ruckstuhl, 2006 at 20, who claims that all influence exerted during the taking of evidence might change the content of the evidence.

${ }^{195}$ Wohlers/Bläsi, 2015 at 159.

${ }^{196}$ Art. 6 (2) CPC.

${ }^{197}$ Fornito, 2000 at 59; Gless/Martin, 2015 at 164; Häring, 2009 at 238.

${ }^{198}$ Gless, 2016 at 130; Gless in Niggli et al., 2014 at art. 141 no. 6; Gless/Martin, 2015 at 163 et seq.; also Fornito, 2000 at 59; Groner, 2011 at 135; Häring, 2009 at 238; Thommen/Samadi, 2016 at 81 et seq., 84; Vest/Eicker, 2005 at 891; Vetterli, 2012 at 456; see also the discussion in the National Council in: Official Bulletin of the National Council, Summer Session 2007 at 955 et seq.

${ }^{199}$ Gless/Martin, 2015 at 164 et seq. with further references. However, also the sanctioning aspect is mentioned, Vetterli, 2012 at 456 with further references.

${ }^{200}$ See above 2.1.1.3.
} 
through art. 139-141 CPC. This regulation, which is unique in Europe, is an important step towards upholding the rule of law. ${ }^{201}$ However, art. $141 \mathrm{CPC}$ leaves some unanswered questions regarding evidence exclusion. ${ }^{202}$

Prior to the adoption of art. 139-141 CPC, evidence exclusion was regulated very differently across cantons. ${ }^{203}$ When the federal legislature drafted art. $141 \mathrm{CPC}$, it adopted principles that were developed based upon an overview of the various cantonal provisions and the requirements of federal law. ${ }^{204}$ However, in contrast to the previous discussion of case law on the matter, ${ }^{205}$ the legislature intended that the admission of unlawfully obtained evidence be the exception rather than the rule. ${ }^{206}$ The new core provisions of the CPC on the exclusion of evidence are found in art. 140 and 141 CPC. Article 140 (1) CPC addresses prohibited methods of obtaining evidence, stating that "the use of coercion, violence, threats, promises, deception and [other] methods that may compromise the ability of the person concerned to think or decide freely are prohibited when taking evidence." Article 140 (2) CPC adds that "such methods remain unlawful even if the person concerned consents to their use."207

As to the legal framework on evidence exclusion, art. 141 CPC constitutes a blanket exclusionary rule and contains 5 sections. It reads:

(1) Evidence obtained in violation of Article 140 is not admissible under any circumstances. The foregoing also applies where this Code declares evidence to be inadmissible.

(2) Evidence that criminal justice authorities have obtained by criminal methods or by violating regulations on admissibility is inadmissible unless it is essential that it be admitted in order to secure a conviction for a serious offence.

(3) Evidence that has been obtained in violation of administrative regulations is admissible.

(4) Where evidence that is inadmissible under paragraph 2 has made it possible to obtain additional evidence, such evidence is not admissible if it would have been impossible to obtain had the previous evidence not been obtained. ${ }^{208}$

\footnotetext{
${ }^{201}$ Gless, 2016 at 128 et seq.; Gless in Niggli et al., 2014 at art. 141 no. 1; Gless, 2012 at 136.

${ }^{202}$ See in detail Häring, 2009 at 118 et seq.; Gless, 2016 at 134.

${ }^{203}$ See the examples in Gless in Niggli et al., 2014 at art. 141 no. 5.

${ }^{204}$ Gless in Niggli et al., 2014 at art. 141 no. 2. See in detail to the legislative process Gless, 2007 at 401 et seq.; Hersch, 2012 at 359, 363, 367, 371 et seq. however, explains in detail various differences between art. 141 (2) CPC and the Supreme Court's case law.

${ }^{205}$ See below 3.1.3.

${ }^{206}$ Vetterli, 2012 at 462 referring to Official Bulletin of the National Council, Summer Session 2007 at 955 et seq.

${ }^{207}$ See generally Gless, 2010 at 149 et seq.

${ }^{208}$ Recent reform efforts plan to amend art. 141 (4) CPC by extending its scope of application also to evidence inadmissible under paragraph 1 of art. $141 \mathrm{CPC}$, see art. 141 (4) of the preliminary draft regarding a reform of the CPC submitted by the Swiss Federal Council in December 2017, available online at <https://www.bj.admin.ch/dam/data/bj/sicherheit/gesetzgebung/aenderungstpo/ vorentw-d.pdf>, accessed 22 November 2018.
} 
(5) Records relating to inadmissible evidence shall be removed from the case documents, held in safekeeping until a final judgment has concluded the proceedings, and then destroyed.

Article 141 CPC does not prescribe the general exclusion of all evidence gathered in violation of the law. Rather, it differentiates between absolute exclusionary rules, relative exclusionary rules, and violations of administrative regulations. $^{209}$

Article 141 (1) CPC establishes the absolute exclusionary rule, which does not allow the use of judicial discretion ${ }^{210}$ : If evidence falls under the auspices of art. 141 (1) CPC, its exclusion is mandatory. ${ }^{211}$ Such evidence includes that which is obtained through explicitly prohibited methods, including coercion, violence, threats, promises, deception and other methods that may compromise the ability of the person concerned to think or decide freely, as well as evidence excluded pursuant to other provisions of the CPC. ${ }^{212}$ The latter includes, for instance, the exclusionary rules found in art. 158 (2) CPC (statements made prior to the accused being informed of the proceedings against them and their legal rights $)^{213}$ and in art. 289 (6) CPC (unauthorized undercover investigations). ${ }^{214}$

Alternatively, art. 141 (2) CPC provides a so-called "relative" exclusionary rule, which gives courts some discretion in deciding the admissibility of evidence. ${ }^{215}$ The exclusionary rule of art. 141 (2) CPC is termed relative because it only excludes evidence in principle. The admission of the same evidence remains possible under art. 141 (2) CPC if it is essential to establish the facts of a serious offence. ${ }^{216}$ This provision applies to evidence gathered through criminal means that do not require exclusion under art. 141 (1) CPC $^{217}$ or evidence gathered in violation of regulations on admissibility (Gültigkeitsvorschriften). Regulations on admissibility are legal provisions deemed so crucial to the safeguarding of individual rights that their objective can only be achieved if their violation results in the invalidity of any subsequent action(s) and the exclusion of evidence garnered. ${ }^{218}$ In contrast, the violation of administrative regulations ${ }^{219}$ does not require the exclusion of evidence

\footnotetext{
${ }^{209}$ Oberholzer, 2012 at no. 702.

${ }^{210} \mathrm{Gless} / \mathrm{Martin}, 2015$ at 167.

${ }^{211}$ Pieth, 2016 at 192; Schmid, 2017 at $§ 58$ no. 793.

${ }^{212}$ See the enumeration in Gless in Niggli et al., 2014 at art. 141 no. 48 et seq.

${ }^{213}$ Pieth, 2016 at 193.

${ }^{214} \mathrm{Gless} /$ Martin, 2015 at 167 et seq.

${ }^{215}$ Gless/Martin, 2015 at 168 et seq.; Pieth, 2016 at 194 et seq.

${ }^{216}$ Oberholzer, 2012 at no. 705.

${ }^{217}$ See in detail Hersch, 2012 at 366 et seq.; also Gless in Niggli et al., 2014 at art. 141 no. 65 as well as the example in Thommen/Samadi, 2016 at 69 et seq. with further references; see also BGE 141 IV 417, consid. 2.

${ }^{218}$ Bundesblatt, 2006 at 1183 et seq.; BGE 139 IV 128, consid. 1.6.

${ }^{219}$ "Designed to guarantee the smooth administration of criminal proceedings", Thommen/Samadi, 2016 at 71; also Vest/Eicker, 2005 at 890.
} 
obtained thereafter (as art. 141 (3) CPC states). It may, however, lead to disciplinary sanctions. $^{220}$

Article 141 (2) CPC is criticized on several fronts. First, it can be difficult to apply as a result of vague verbiage, which has led to numerous attempts at defining the terms "serious offence"221 and "essential.",222 The differentiation between regulations on admissibility and administrative regulations has also been critiqued. ${ }^{223}$ As regulations on admissibility have the primary aim of safeguarding individual rights, it should follow that their violation always results in the evidence being excluded without any exceptions. ${ }^{224}$ However, the exception for serious offences found in Art. 141 (2) CPC negates this rationale and more or less implies that the severity of the crime committed can justify the violation of procedural rules (or even crimes) by the police and may even encourage such misconduct. ${ }^{225}$ This idea has been summed up in the legal literature using the phrase: "The bigger the crime, the smaller the chance of a fair trial. ${ }^{, 226}$ It is undeniable that defendants accused of serious offenses are in greater need of procedural safeguards yet it is in this very context that a defendant's rights are most often compromised. ${ }^{227}$ To minimize the problems raised by art. 141 (2) CPC, the admission of illegally obtained evidence should only be considered if other interests such as the accused's individual rights do not disproportionately outweigh the public interest in fighting crime. ${ }^{228}$

Ultimately, it is problematic to give courts the discretion to balance competing interests when it comes to the exclusion of evidence. Additionally, it is much more difficult for a court to knowingly acquit a guilty defendant by excluding evidence than it is for the legislature to set procedural limitations to the search for truth in order to secure fair trials. ${ }^{229}$ As such, a more definitive rule would be preferable. On the other hand, exclusionary rules that are too strict and do not provide the courts with any discretion can also lead to judges finding ways to reassert their authority

\footnotetext{
${ }^{220}$ Thommen/Samadi, 2016 at 71.

${ }^{221}$ Gless in Niggli et al., 2014 at art. 141 no. 72 ; Hersch, 2012 at 368 et seq.; Ruckstuhl et al., 2011 at no. 556; Wohlers/Bläsi, 2015 at 164 et seq., all with further references.

${ }^{222}$ It is particularly disputed whether a balancing approach is still possible under the terms of art. 141 (2) CPC; see Hersch, 2012 at 369 et seq. with further references; see also below at 3.3.; Ruckstuhl et al., 2011 at no. 557, however, state that the term "essential" has no independent significance.

${ }^{223}$ Donatsch/Cavegn, 2008 at 165 et seq. with further critical points; also Fornito, 2000 at 239 et seq.; Gless in Niggli et al., 2014 at art. 141 no. 74; Häring, 2009 at 239 et seq.; Keller, 2011 at 245; Vest/Höhener, 2009 at 102; Vetterli, 2012 at 463.

${ }^{224}$ Vetterli, 2012 at 463.

${ }^{225}$ Thommen/Samadi, 2016 at 84 et seq.; Vest/Eicker, 2005 at 891; Vest/Höhener, 2009 at 103.

${ }^{226}$ Thommen/Samadi, 2016 at 85 et seq.

${ }^{227}$ Gless, 2010 at 157; Gless, 2012 at 140; Oberholzer, 2012 at no. 706; Fornito, 2000 at 250; Vest/ Eicker, 2005 at 891; also Vest/Höhener, 2009 at 103; Vetterli, 2012 at 457; Thommen/Samadi, 2016 at 84 .

${ }^{228}$ Gless/Martin, 2015 at 169.

${ }^{229}$ Vetterli, 2012 at 458 et seq.
} 
by creatively interpreting the provisions and potentially encouraging their nonenforcement. ${ }^{230}$

A distinct provision of the Swiss CPC is art. 141 (4), which excludes indirect (or derivative) evidence that would have been impossible to obtain without the use of evidence deemed inadmissible under art. 141 (2) CPC. ${ }^{231}$ This is unique because the fruit of the poisonous tree doctrine, while typical of adversarial systems, is rarely found in inquisitorial criminal justice systems.

\subsubsection{Jurisprudence of the Supreme Court}

The Swiss CPC established a legal framework of fairly strict exclusionary rules. This led to conflicts in their application because, among other things, Swiss courts had formerly enjoyed wide discretion in the application of their respective cantonal codes. $^{232}$ The Swiss Supreme Court was previously using a balancing approach to evidence exclusion in criminal proceedings. Under this approach, the question of whether or not a piece of evidence was admissible at trial was determined by the court after balancing the varying interests of the particular case. ${ }^{233}$ While this allowed for a thorough consideration of all aspects of the particular case, it included with it the risk that courts would justify purely subjective decisions. ${ }^{234}$ It also had the potential of leading to inconsistent decisions across cases, as is highlighted by the Supreme Court's case law on exclusionary rules. ${ }^{235}$

Today, the strict exclusionary rules of the CPC grant little discretional power to the courts. ${ }^{236}$ Courts are allowed to return to a balancing approach only where the CPC fails to give an answer about the admissibility of a particular piece of evidence. This is the case for the exclusion of evidence resulting from principles based on so-called autonomous exclusionary rules ("selbständige Beweisverwertungsverbote"), or the taking of evidence through private individuals, and the exclusion of exonerating

\footnotetext{
${ }^{230}$ Gless/Martin, 2015 at 179 et seq.

${ }^{231}$ However, recent reform efforts plan to amend art. 141 (4) CPC by extending its scope of application also to evidence inadmissible under paragraph 1 of art. 141 CPC, see art. 141 (4) of the preliminary draft regarding a reform of the CPC submitted by the Swiss Federal Council in December 2017, available online at <https://www.bj.admin.ch/dam/data/bj/sicherheit/ gesetzgebung/aenderungstpo/vorentw-d.pdf>, accessed 22 November 2018.

${ }^{232}$ Gless/Martin, 2015 at 160 et seq.

${ }^{233}$ BGE 130 I 126, consid. 3.2.; BGE 120 Ia 314, consid. 2.d.

${ }^{234}$ Wohlers/Bläsi, 2015 at 160; also Fornito, 2000 at 248 et seq.; Häring, 2009 at 245 et seq.; Vest/ Eicker, 2005 at 890 et seq.

${ }^{235}$ Vest/Höhener, 2009 at 102 et seq.

${ }^{236}$ Gless/Martin, 2015 at 171.
} 
evidence. ${ }^{237}$ However, the restriction of discretion through art. $141 \mathrm{CPC}$ should not be overestimated either given that the legislature sought to codify the current jurisdiction of the Supreme Court with this provision. ${ }^{238}$ Despite this rationale, there are some deviations. Section 2 of art. 141 CPC, in particular, differs from the Supreme Court's earlier case law. ${ }^{239}$ Specifically, the provision only allows evidence obtained by illegal means or in violation of regulations on admissibility to be admitted if it is essential to the resolution of a serious offense. The statute does not mention the additional balancing criteria the Supreme Court had been relying upon in the case law up to that point, including the determination of whether the evidence could have been obtained legally ${ }^{240}$ and the application of the principle of a fair trial. ${ }^{241}$ The continued applicability of such criteria under the terms of art. 141 (2) CPC is disputed in the legal literature. ${ }^{242}$

In addition to the aforementioned changes, the legislature has emphasized that the exclusion of evidence under the terms of art. 141 (2) CPC (which does leave some discretion to the courts) should be the rule and that the admission of evidence gathered by violation of regulations on admissibility or a criminal offense must be the exception. ${ }^{243}$ Before the CPC was enacted, the Supreme Court made the exclusion of evidence the exception rather than the rule by applying the balancing approach. ${ }^{244}$ Under this approach an increasing number of minor offenses were classified as "serious offence" for the purposes of evidence admission. ${ }^{245}$ However, in a more recent judgement (still under cantonal law) the Supreme Court stated that offenses punishable by imprisonment up to three years or a fine ("Vergehen") ${ }^{246}$ represent relatively

\footnotetext{
${ }^{237}$ See in detail Häring, 2009 at 118 et seq.; also BGE 133 IV 329 consid. 4.4., referring to exclusionary rules explicitly mentioned in a special law. Autonomous exclusionary rules provide for the exclusion of legally obtained evidence in case that other interests outweigh the interest in using the evidence, Gless in Niggli et al., 2014 at art. 141 no. 9 et seq.; Vest/Höhener, 2009 at 98 et seq.; Wohlers/Bläsi, 2015 at 160 and 161 et seq.

${ }^{238}$ See above 3.1.2.

${ }^{239}$ See Hersch, 2012 at $363,367,371$ et seq.

${ }^{240}$ BGE 130 I 126, consid. 3.2; BGE 103 Ia 206 consid. 9.b.; BGE 96 I 437, consid. 3.b.; Vest/ Eicker, 2005 at 889, 892; Vest/Höhener, 2009 at 105 et seq.

${ }^{241}$ BGE 137 I 224; BGE 131 I 272 consid. 3.2.3.5 et seq.; Vest/Höhener, 2009 at 103; Vetterli, 2012 at 460 et seq.

${ }^{242}$ Answering in the negative Hersch, 2012 at 361, 367 et seq., 372 with further references; also Wohlers/Bläsi, 2015 at 164 et seq.; Häring, 2009 at 243 et seq. on the other hand, points out that the legislator wanted to establish a balancing approach, however limited.

${ }^{243}$ The discussion in the National Council in: Official Bulletin of the National Council, Summer Session 2007 at 955 et seq.; also Vetterli, 2012 at 462; Hersch, 2012 at 367 et seq.; Vest/Höhener, 2009 at 107.

${ }^{244}$ See in detail Vest/Höhener, 2009 at 95 et seq.; also Hersch, 2012 at 358; Keller, 2011 at 234; Vetterli, 2012 at 458.

${ }^{245}$ Vetterli, 2012 at 458 et seq. with further references.

${ }^{246}$ Art. 10 (3) Swiss Criminal Code (SCC) of 21 December 1937 (Status as of 1 January 2017), available online at <https://www.admin.ch/opc/en/classified-compilation/19370083/index.html>, accessed 22 November 2018.
} 
grave, but not very serious offenses, thereby ruling in favor of excluding illegally obtained evidence in these cases. ${ }^{247}$ This judgment was commended by legal scholars and said to mark an important change in the Court's jurisprudence. ${ }^{248}$

Despite some changes, the Swiss Supreme Court has generally continued to try to find ways to preserve its balancing power since the CPC was enacted. ${ }^{249}$ This is especially the case in its restrictive application of the absolute exclusionary rule (cf. art. 141 (1) CPC) and the fruit of the poisonous tree doctrine (cf. art. 141 (4) CPC). ${ }^{250}$ Since the Supreme Court did not elaborate on clear criteria for the distinction between regulations on admissibility (cf. art. 141 (2) CPC) or mere administrative regulations, there has been a tendency for evidence to be admitted. ${ }^{251}$ At the same time, it has also categorized several important provisions (e.g. the search of a person without a warrant) as administrative regulations, ${ }^{252}$ thereby allowing the admission of evidence obtained through their violation. ${ }^{253}$ This practice has rightfully been criticized by legal scholars. ${ }^{254}$ It is not the case, however, that the Supreme Court categorically admits evidence wherever possible; there have been other situations where it has decided to exclude evidence. ${ }^{255}$

\subsubsection{Enforcement of Exclusionary Rules}

Violations of procedural rules and individual rights by the prosecution authorities cannot be undone. The negative consequences for the defendant, however, can be eliminated effectively through exclusionary rules where any tainted (incriminating) evidence is removed in its entirety from the file and not considered in the judgment. ${ }^{256}$ The Code endorses this idea in Art. 141 (5) CPC which stipulates that all records relating to excluded evidence must be removed from the criminal files and kept separately until the final judgment, after which they are to be destroyed. Therefore, the excluded evidence should not be available to the prosecuting

\footnotetext{
${ }^{247}$ BGE 137 I 218, consid. 2.3.5.2.; the recent cantonal decision of the Kantonsgericht Schwyz, Strafkammer, of 20 June 2017, STK 2017 1, consid. 4.b.

${ }^{248}$ Vetterli, 2012 at 461.

${ }^{249}$ Gless/Martin, 2015 at 178 (referring to BGE 138 IV 169), 179 et seq., with further references.

${ }^{250}$ Wohlers/Bläsi, 2015 at 169; regarding the jurisprudence on the exclusion of indirect evidence, see below 3.2.5.2.

${ }^{251}$ Wohlers/Bläsi, 2015 at 164; also Gless, 2010 at 156; Gless, 2012 at 139; Gless in Niggli et al., 2014 at art. 141 no. 74; Vest/Höhener, 2009 at 102.

${ }^{252}$ See, for instance, BGE 141 IV 423, consid. 3 regarding the legal instruction of judicial experts.

${ }^{253}$ BGE 139 IV 128, consid. 1.7.; see also the examples in Gless in Niggli et al., 2014 at art. 141 no. 74

${ }^{254}$ Thommen/Samadi, 2016 at 71; Wohlers/Bläsi, 2015 at 166.

${ }^{255}$ For instance, BGer 6B_1025/2016 of 24 October 2017, consid. 1; BGer 6B_656/2015 of 16 December 2016, consid. 1; BGE 141 IV 220, consid. 5.

${ }^{256}$ Vetterli, 2012 at 455 et seq.
} 
authorities at any point in time during the investigation or court proceedings. ${ }^{257} \mathrm{At}$ first sight, art. 141 (5) CPC seems to specify clear rules, but in practice its application has led to problems, particularly where the excluded evidence relates to more than one defendant or is (also) potentially exonerating. ${ }^{258}$

Another issue with the CPC is that it does not contain any provisions addressing the way in which the exclusionary rules are to be enforced. ${ }^{259}$ Specifically, the CPC does not outline which authority (judge(s) of fact, judges within the appellate body, or another authority) should decide the admissibility of evidence and at which stage of the proceedings. Typically, the judge(s) offact decide ${ }^{260}$ all substantive questions based on the complete criminal file, generally in the form of a conviction or an acquittal. The court of appeal is then tasked with examining only specifically contested procedural steps based on excerpts from the case file and providing an opinion in the form of an interim decision. ${ }^{261}$

The Swiss Supreme Court holds that the judges of fact have the authority to determine whether or not to exclude evidence from the main trial, ${ }^{262}$ although there are some exceptions, for example, where the law $^{263}$ explicitly stipulates the immediate restitution or destruction of illegally obtained evidence. ${ }^{264}$ There, the prosecution is required to exclude the evidence during the preliminary investigation. ${ }^{265}$ With respect to illegally obtained confessions, the Supreme Court held that judges of fact should not have access to the confession for fear that they may consider it in the final judgment despite its exclusion. ${ }^{266}$ Unfortunately, the Supreme Court has not elaborated on this last exception. In fact, it has made inconsistent statements on the matter, commenting that it is not in and of itself a problem that judges of fact have knowledge of illegally obtained evidence because they can be expected to refrain from considering it in their decisions. ${ }^{267}$

\footnotetext{
${ }^{257}$ Donatsch/Schwarzenegger/Wohlers, 2014 at 122.

${ }^{258}$ Donatsch/Schwarzenegger/Wohlers, 2014 at 122.

${ }^{259}$ Geisselhardt, 2014 at 300.

${ }^{260}$ Depending on the canton, the instance and the case, the court can consist of a single judge, three or five judges, Oberholzer, 2012 at no. 99 et seq.; art. 19 (2) CPC, art. 395 CPC.

${ }^{261}$ See generally Geisselhardt, 2014 at 300 et seq.

${ }^{262}$ BGE 141 IV 289, consid. 1.2.; BGer 1B-179/2012 of 13 April 2012, consid. 2.4.; also BGE 120 Ia 314, consid. 2.c. et seq., saying that evidence may be excluded in the trial. In BGE 122 I 182, consid. 4.c. (a decision dating from 1996 on evidence obtained by telephone tapping), however, the SSC emphasized that in certain cases the exclusion of evidence by a court may be necessary even during the preliminary proceedings.

${ }^{263}$ See e.g, art. $277 \mathrm{CPC}$ (on the monitoring of post and telecommunications) or art. 289 (6) CPC (on undercover investigations).

${ }^{264}$ BGE 141 IV 284, consid. 2.3.; BGE 141 IV 289, consid. 1.3.

${ }^{265}$ Hansjakob in Donatsch et al., 2014 at art. 277 no. 10, regarding art. 277 CPC on the findings of unauthorized surveillence.

${ }^{266}$ BGer 1B_445/2013 of 14 February 2014, consid. 1.2 et seq.; also BGer 1B_124/2014 of 21 May 2014, consid. 1.2.3.; also BGE 122 I 182, consid. 4.c).

${ }^{267}$ BGE 141 IV 289, consid. 1.2.; also BGer 1B_124/2014 of 21 May 2014, consid. 1.2.4.
} 
The jurisdiction of the judge(s) of fact remains disputed by legal scholars. Some agree with the Supreme Court's view because art. 343 (2) CPC stipulates that judges of fact are competent to re-take improperly obtained evidence during preliminary proceedings. ${ }^{268}$ This is related to the idea that judges of fact should have unrestricted access to all available evidence ${ }^{269}$ because only then can they fully evaluate the interests of all parties involved and make a determination as to whether the proceedings as a whole are fair. ${ }^{270}$ Other scholars, however, have made convincing arguments criticizing the jurisdiction of judges of fact based upon the premise that the subsequent removal of evidence from the files does not erase the judges' knowledge of it. As a result, it is likely that they will still consider excluded evidence in their decisions, ${ }^{271}$ which significantly reduces the effectiveness of exclusionary rules. This is even more problematic when crucial incriminating evidence is involved because judges seem to have difficulty in acquitting a defendant that is apparently guilty. ${ }^{272}$ Furthermore, because exclusionary rules are binding at all stages of the judicial process, they must be considered in every procedural decision - and always with the same standards. ${ }^{273}$ This is particularly important given the fact that, practically speaking, the police exert significant influence over the fact-finding process. ${ }^{274}$ They should, therefore, also investigate exonerating evidence and potentially even implement exclusionary rules in order to effectively secure a fair trial. Thus, it seems preferable to grant defendants the right to request that evidence be excluded (and the right to appeal a denial of this request)

\footnotetext{
${ }^{268}$ Geisselhardt, 2014 at 301, 304, with exceptions at 305; also Groner, 2011 at 142; Oberholzer, 2012 at no. 714. However, art. 343 (2) CPC only stipulates that the court should re-take evidence in case it was improperly obtained in the preliminary proceedings, but it does not prohibit another authority to decide on the exclusion of the improperly obtained evidence.

${ }^{269}$ Geisselhardt, 2014 at 301, 302, 304; also Oberholzer, 2012 at no. 714. Gless in Niggli et al., 2014 at art. 139 no. 15 , however, argues that only lawfully obtained evidence may be the basis for the free assessment of evidence.

${ }^{270}$ Geisselhardt, 2014 at 302 et seq., 304; differing, however Wohlers/Bläsi, 2015 at 171.

${ }^{271}$ Wohlers, 2016 at 430 et seq.; Wohlers/Bläsi, 2015 at 169 et seq.; also the illustration of this problem in Gless, 2013 at 346; the same argument in BGE 122 I 182, consid. 4.c. on evidence obtained by telephone tapping: "Zudem besteht stets die Gefahr, dass der einmal zur Kenntnis genommene Inhalt von Schriftstücken auch bei förmlicher Entfernung aus den Akten haften bleibt und Entscheidungen mitbeeinflussen kann. Aus Gründen eines wirksamen Grundrechtsschutzes ist es daher nach Art. 36 Abs. 4 BV geboten, dass auf entsprechenden Antrag hin die Zulässigkeit der Telefonabhörung von Gesprächspartnern des Beschuldigten und Mitbenützern des überwachten Telefonanschlusses bereits im Untersuchungsstadium geprüft wird." Differing, however, BGE 141 IV 289, consid. 1.2. "Von diesem [dem Sachrichter] kann erwartet werden, dass er in der Lage ist, die unzulässigen Beweise von den zulässigen zu unterscheiden und sich bei der Würdigung ausschliesslich auf Letztere zu stützen.” As well as BGer 1B_124/2014 of 21 May 2014, consid. 1.2.2., differentiating, however, in consid. 1.2.3., referring to BGer 1B_445/2013 of 14 February 2014, consid. 1.2 et seq.

${ }^{272}$ Vetterli, 2012 at 457 et seq.

${ }^{273}$ Gless in Niggli et al., 2014 at art. 141 no. 35.

${ }^{274}$ See above 2.1.3.1.
} 
during preliminary proceedings. ${ }^{275}$ However, the authority that judges of fact have over the application of exclusionary rules does not equate to sole control over exclusionary rules. Rather, it should be the duty of the acting authority at each stage of the proceedings (police, public prosecution, judges) to examine whether evidence must be excluded - even if in the end judges of fact view it anyway.

Under Swiss law, if a party to criminal proceedings (particularly an accused) wants to make a motion for the exclusion of evidence, he or she can submit a request to the person in charge of the proceedings. ${ }^{276}$ This is possible during both the pre-trial proceedings ${ }^{277}$ or the main hearing. ${ }^{278}$ It is recommended that the request be submitted as soon as practicably possible - in fact, if the exclusionary rule is not invoked until the appeal proceedings, the defendant might be considered to be capitalizing on the situation and his or her request denied as a result. ${ }^{279}$ Depending on the stage of the proceedings, the prosecution or the court determines whether to exclude evidence in an interim decision. ${ }^{280}$ The Supreme Court has held that until such a decision is made, the evidence in question may still be used for intermediate decisions and to support further investigation, unless it is a priori inadmissible. ${ }^{281}$ In order to estimate whether unauthorized compulsory techniques have been used, the courts rely on the continual documentation and recording of the evidence collected. $^{282}$

According to the jurisprudence of the Supreme Court, where the request to exclude evidence is denied, there is no right to object ${ }^{283}$ except where mentioned above. Under these exceptions, the defendant has the opportunity to appeal the interim decision not to exclude evidence to an appellate court and, if necessary, the Swiss Supreme Court. For cases that do not fall under one of the exceptions, the aggrieved party is free to repeat the request for exclusion ${ }^{284}$ or, alternatively, appeal the final decision ${ }^{285}$ if based upon the contested evidence. ${ }^{286}$ The court of appeals

\footnotetext{
${ }^{275}$ Also Wohlers/Bläsi, 2015 at 174.

${ }^{276}$ Wohlers in Donatsch et al., 2014 at art. 141 no. 10a.

${ }^{277}$ Donatsch/Schwarzenegger/Wohlers, 2014 at 122.

${ }^{278}$ Art. 339 (1) lit. d CPC; Oberholzer, 2012 at no. 714.

${ }^{279}$ Oberholzer, 2012 at no. 716 and BGE 138 I 97, consid. 4.2.4.; dissenting Bürge, 2017 at 324.

In BGE 129 I 85, consid. 4.4., however, the SSC stated that the right to request the exclusion of improperly obtained evidence can also be asserted in appeal proceedings.

${ }^{280}$ See, amongst others, BGE 141 IV 289, consid. 1.1.

${ }^{281}$ BGer 1B_2/2013 of 5 June 2013, consid. 1.2.; BGer 1B_179/2012 of 13 April 2012, consid. 2.4.; differing Wohlers in Donatsch et al., 2014 at art. 141 no. 1 with further references.

${ }^{282}$ Gless in Niggli et al., 2014 at art. 140 no. 75; also art. 76 et seq. CPC; Oberholzer, 2012 at no. 699 .

${ }^{283}$ BGer 1B_414/2012 of 20 September 2012, consid. 1.2.; BGer 1B_584/2011 of 12 December 2011, consid. 3.2.

${ }^{284}$ BGE 141 IV 289, consid. 2.7.

${ }^{285}$ Art. 398 CPC; BGE 141 IV 289, consid. 1.2.; Wohlers in Donatsch et al., 2014 at art. 141 no. $10 \mathrm{~b}$.

${ }^{286}$ Groner, 2011 at 143; BGer 6P.124/2002 of 6 October 2003, consid. 5.
} 
will then evaluate the lower court's consideration of the evidence, including the issue of admissibility. ${ }^{287}$ After all cantonal legal remedies are exhausted, a defendant may appeal to the Swiss Supreme Court. ${ }^{288}$ If, at any point during the process, a court holds that evidence has been obtained improperly and, therefore, must be excluded, the evidence may not be considered in the final judgment. ${ }^{289}$ The court must then re-take the evidence, ${ }^{290}$ but only within the scope of art. 141 (4) CPC. ${ }^{291}$

\subsection{Exclusion of Illegally Obtained Evidence Following Improper Compulsory Techniques}

\subsubsection{The Right Against Self-Incrimination and Improper Compulsory Measures}

The legal authority for the right against self-incrimination can be found in both domestic and international law. First, it is expressly codified in art. 113 CPC, which states, "The accused may not be compelled to incriminate him or herself. In particular, the accused is entitled to refuse to make a statement or to cooperate in the criminal proceedings. He or she must however submit to the compulsory measures provided for by the law." At the international level, the right against self-incrimination is considered by the European Court of Human Rights (ECtHR) to be one of the most important components of a fair trial and is guaranteed by art. 6 (1) of the ECHR. ${ }^{292}$ It is also explicitly mentioned in art. 14 (3) lit. g of the ICCPR II.

The right against self-incrimination hypothetically grants a defendant the right to refuse to collaborate whatsoever at any point during criminal proceedings. ${ }^{293}$ As a result, prosecution authorities are not allowed to improperly compel ${ }^{294}$ a defendant

\footnotetext{
${ }^{287}$ Oberholzer, 2012 at no. 714 .

${ }^{288}$ Gless in Niggli et al., 2014 at art. 141 no. 121; BGE 141 IV 289, consid. 1.2.; Wohlers/Bläsi, 2015 at 174 argue that already the interim decision on the exclusion of evidence should be contestable.

${ }^{289}$ Groner, 2011 at 141.

${ }^{290}$ BGer 6B_690/2015 of 25 November 2015, consid. 3.4.; art. 343 (2) CPC.

${ }^{291}$ Häring, 2009 at 253; see also above 3.1.4.

${ }^{292}$ European Court of Human Rights (ECtHR), Saunders v. United Kingdom, case no. 19187/91, Judgment (Grand Chamber) of 17 December 1996, § 68.

${ }^{293}$ Lieber in Donatsch et al., 2014 at art. 113 no. 1.

${ }^{294}$ ECtHR, Saunders v. United Kingdom, case no. 19187/91, Judgment (Grand Chamber) of 17 December 1996, § 68; see also BGE 131 IV 36, consid. 3.1.
} 
to collaborate. ${ }^{295}$ Whilst the authorities are permitted to use compulsory measures under certain circumstances, ${ }^{296}$ including searching people and their property ${ }^{297}$ and tapping their phones, ${ }^{298}$ art. 140 (1) states that "the use of coercion, violence, threats, promises, deception and [other] methods that may compromise the ability of the person concerned to think or decide freely are prohibited when taking evidence." ${ }^{299}$ Accordingly, coercing a defendant is improper and violates the right against self-incrimination where it aims to influence or break the will of a defendant. $^{300}$ Article 140 (1) CPC applies to any point during which time evidence is taken, although traditionally it referred solely to the interrogation of an accused. ${ }^{301}$

\subsubsection{Torture and Inhuman or Degrading Treatment}

Law enforcement authorities are limited by all individuals' inherent and inalienable right to dignity, which is absolute and cannot be outweighed by other interests. ${ }^{302}$ As a consequence, art. 3 and 15 (2) ECHR, art. 7 and 4 (2) ICCPR II, art. 10 (3) $\mathrm{BV}$, as well as art. 3 (2) lit. d CPC strictly prohibit gathering evidence in any manner that violates human dignity, including the use of torture and degrading treatment. The classification of any technique depends on the specific circumstances of the case, such as the duration and consequences, as well as the age, sex, and current state of health of the affected person. ${ }^{303}$ According to art. 1 (1) UN Convention Against Torture (CAT), ${ }^{304}$ torture includes "any act by which severe pain or suffering, whether physical or mental, is intentionally inflicted on a person." However, this high threshold required for an act to constitute torture has been lowered in recent years. ${ }^{305}$ Additionally, inhuman treatment is defined as that which causes injuries or intense physical or psychological pain ${ }^{306}$ while degrading

\footnotetext{
${ }^{295}$ Lieber in Donatsch et al., 2014 at art. 113 no. 37. In detail, however, it is quite controversial what is meant by "improper compulsion", see e.g., Macula, 2016 at. 24 et seq. with further references.

${ }^{296}$ As art. 113 (1) CPC explicitly states.

${ }^{297}$ Art. 249 et seq. CPC.

${ }^{298}$ Art. 269 et seq. CPC.

${ }^{299}$ For a detailed definition of those methods, see Gless in Niggli et al., 2014 at art. 140 no. 32 et seq.; Wohlers, in Donatsch et al., 2014 at art. 140 no. 3 et seq.

${ }^{300}$ Lieber in Donatsch et al. 2014 at art. 113 no. 44 with further references.

${ }^{301}$ Gless in Niggli et al., 2014 at art. 140 no. 21 et seq.

${ }^{302}$ Wohlers, in Donatsch et al., 2014 at art. 3 no. 5 with further references.

${ }^{303}$ Wohlers, in Donatsch et al., 2014 at art. 3 no. 47 et seq. and 50 with further references.

${ }^{304}$ Of 10 December 1984, available online at <www.ohchr.org/Documents/ProfessionalInterest/ cat.pdf>, accessed 22 November 2018 .

${ }^{305}$ Wohlers, in Donatsch et al., 2014 at art. 3 no. 48 with further references.

${ }^{306}$ Wohlers, in Donatsch et al., 2014 at art. 3 no. 49 with further references.
} 
treatment involves the causing of pain or degradation, for example through corporal punishment or the threat of torture. ${ }^{307}$

\subsubsection{Institutional Bans on Torture and the Right to Remain Silent}

Swiss law provides several institutional measures banning torture and preserving the right to remain silent, which are included in the discussion of remedies (supervision, disciplinary, and criminal liability) above, although their enforcement is problematic due to a fragmented statutory code and restricted legal practice. ${ }^{308}$ Other legal remedies also exist ${ }^{309}$ and a large majority of the cantons have introduced a duty for doctors to report any violations of a patient's physical or mental well-being observable to them in their medical practice. ${ }^{310}$ Within this system of safeguarding individual rights, exclusionary rules are of the utmost importance - at least in theory.

\subsubsection{Exclusionary Rules Applicable to Illegally Obtained Evidence}

\subsubsection{Legal Framework}

Evidence obtained through torture or other improper compulsory techniques violates art. 140 (1) CPC (prohibited methods of taking evidence) and triggers the absolute exclusionary rule of art. 141 (1) CPC. The exclusion of such evidence is mandatory, without exception, and is not subject to judicial discretion. ${ }^{311}$

The CPC does not outline a standard procedure to determine whether improper compulsory procedures have been used in an investigation. However, some cantons have established specific protocols in cases of criminal complaints alleging police abuse. ${ }^{312}$ A study by the Swiss Centre of Expertise in Human Rights (SCHR) found numerous media reports on alleged abuse by police in Switzerland, ${ }^{313}$ but none of the cases studied involved violations with the specific intent of obtaining evidence from an accused. If a defendant alleges that evidence-a confession for instancehas been obtained in violation of the $\mathrm{CPC}$, but cannot prove it, the reliability and significance of such evidence is at the discretion of the court due to the principle of

\footnotetext{
${ }^{307}$ Wohlers, in Donatsch et al., 2014 at art. 3 no. 50 with further references. As to the threat of torture, see ECtHR, Gäfgen v. Germany, case no. 22978/05, Judgment (Grand Chamber) of 1 June 2010, § 65, 69.

${ }^{308}$ See above 3.1.2 et seq. and below 3.2.4 et seq.

${ }^{309}$ See above 2.1.3.2 et seq.

${ }^{310}$ In the other cantons, the doctor must previously seek to be released from his or her duty to maintain secrecy; see CAT Report, 2016 at 2 et seq.

${ }^{311}$ Pieth, 2016 at 192; Schmid, 2017 at $\$ 58$ no. 793.

${ }^{312}$ See below 2.1.3.3.

${ }^{313}$ Künzli et al., 2014 at 6 et seq. with further references.
} 
unrestricted access to evidence. ${ }^{314}$ However, recent reform efforts plan to amend the CPC by adding a new art. 78a CPC on the recording of interviews with technical devices (such as videotaping). Such recording techniques provide an important tool to monitor interviews and to ensure that police and prosecutors adhere to procedural rules. $^{315}$

\subsubsection{Jurisprudence of the Supreme Court}

As mentioned above, the mandatory exclusionary rule of art. 141 (1) CPC leaves no discretion to the courts. ${ }^{316}$ However, art. 140 (1) CPC leaves some room for the courts to specify "methods that may compromise the ability of the person concerned to think or decide freely." Swiss Supreme Court case law on this issue indicates that prohibited methods under this section include inducing intoxication with alcohol, ${ }^{317}$ using a lie detector, ${ }^{318}$ and using narcoanalysis ("truth serum"). ${ }^{319}$ By contrast, the Supreme Court tends to find evidence admissible that has been obtained through cooperation duties of administrative law. ${ }^{320}$

The use of torture in criminal proceedings does not appear to be a major problem in Switzerland. Cases decided by the Supreme Court have primarily addressed issues around conditions of detention and imprisonment, ${ }^{321}$ not compulsory techniques in evidence gathering.

\subsubsection{Admissibility of Fruit of Poisonous Tree in Cases of Torture and Improper Compulsory Techniques}

\subsubsection{Legal Framework}

Article 141 (4) CPC creates a limited version of the fruit of the poisonous tree doctrine (i.e. the exclusion of indirect evidence). As previously mentioned, such provisions are uncommon in inquisitorial criminal procedure systems as they stem from adversarial criminal justice systems. As a result, there can be problems with

\footnotetext{
${ }^{314}$ Art. 10 (3) CPC, see above 2.1.1.1.

${ }^{315}$ See art. 78a of the preliminary draft regarding a reform of the CPC submitted by the Swiss Federal Council in December 2017, available online at <https://www.bj.admin.ch/dam/data/bj/ sicherheit/gesetzgebung/aenderungstpo/vorentw-d.pdf>, accessed 22 November 2018.

${ }^{316}$ See above, 3.1.2.

${ }^{317}$ BGE 90 I 29, consid. 5.b.

${ }^{318}$ BGE 109 Ia 273 , consid. 7.

${ }^{319}$ BGE 118 Ia 28 , consid. 1.c.

${ }^{320}$ Macula, 2016 at 51 et seq.; see also, for instance, BGE 142 IV 207, consid. 8 et seq.; BGE 140 II 384 , consid. 3.

${ }^{321}$ BGE 141 I 141; BGE 141 IV 423; BGE 140 I 246, consid. 2.4.2.; BGE 139 IV 41.
} 
applying the doctrine. ${ }^{322}$ Article 141 (4) CPC codifies the Swiss Supreme Court's case law since $2007^{323}$ on indirect evidence. ${ }^{324}$ The provision states that such evidence "shall not be used, if it would not have been possible to obtain it, without relying on the previously obtained evidence." ${ }^{, 325}$ Thus, the legislature opted to create a statute that excluded some, but not all indirect evidence. ${ }^{326}$

Specifically, Art. 141 (4) CPC excludes only evidence that would not have been possible to obtain without relying on evidence deemed inadmissible under art. 141 (2) CPC. Thus, the legal text of section 4 paradoxically does not explicitly exclude indirect evidence based on primary evidence obtained by torture and other illegal compulsory techniques. The legislature did, however, require the strict exclusion of any evidence in these cases, which implicitly includes also indirect evidence. ${ }^{327}$ Legal scholars agree that evidence excluded under the terms of the more stringent art. 141 (1) CPC must a fortiori include exclusion of subsequent, indirect evidence, ${ }^{328}$ but they do not agree on the details. Whilst the prevailing theory advocates for the strict exclusion of indirect evidence obtained following a violation of art. 141 (1) $\mathrm{CPC},{ }^{329}$ other scholars argue for the application of the limited exclusionary rule stipulated in art. 141 (4) $\mathrm{CPC}^{330}$ As a consequence of these debates, recent reform efforts plan to amend art. 141 (4) CPC by extending its scope of application explicitly to evidence inadmissible under paragraph 1 and 2 of art. 141 CPC. $^{331}$

The exclusion of indirect evidence should also be considered where authorities seek to re-take improperly obtained evidence. In light of art. 141 (4) CPC, not only is the illegally gathered evidence tainted, but so is the knowledge acquired through

\footnotetext{
${ }^{322} \mathrm{Gless} / \mathrm{Martin}, 2015$ at 161 with further references.

${ }^{323}$ BGer 6B_211/2009 of 22 June 2009, consid. 1.4.2.; BGE 134 IV 266, consid. 5.3.; BGE 133 IV 329 , consid. 4.5.

${ }^{324}$ Wohlers/Bläsi, 2015 at 167.

${ }^{325}$ See the English translation of art. 141 (4) in Wohlers in Donatsch et al., 2014 at 703.

${ }^{326}$ Keller, 2011 at 246.

${ }^{327}$ The discussion in the Council of States, in: Official Bulletin of Council of States, Winter Session 2006 at 1014: „,Une preuve indirecte est également inexploitable si la première preuve a été obtenue par la violation de prescriptions qui la rend inexploitable. Il y a une exception qui découle de la dernière partie de l'alinéa 2 qui dit que la première preuve est exploitable à certaines conditions"; also Pieth, 2016 at 199 and Vetterli, 2012 at 466 both with further references.

${ }^{328}$ Gless in Niggli et al., 2014 at art. 141 no. 90; Ruckstuhl et al., 2011 at no. 565; Pieth, 2016 at 199; Wohlers in Donatsch et al., 2014 at art. 141 no. 14, all with further references.

${ }^{329}$ Gless, 2010 at 159; Gless, 2012 at 142; Häring, 2009 at 251; Pieth, 2016 at 199 with further references; Wohlers/Bläsi, 2015 at. 166 et seq.

${ }^{330}$ Since the unlimited exclusion would be exaggerated, see Vetterli, 2012 at 466.

${ }^{331}$ See art. 141 (4) of the preliminary draft regarding a reform of the CPC submitted by the Swiss Federal Council in December 2017, available online at <https://www.bj.admin.ch/dam/data/bj/ sicherheit/gesetzgebung/aenderungstpo/vorentw-d.pdf>, accessed 22 November 2018.
} 
it. Therefore, the re-taking of such evidence should only be possible where it conforms to the limitations set forth in art. 141 (4) CPC. ${ }^{332}$

\subsubsection{Jurisprudence of the Supreme Court}

Until quite recently, the question of whether evidence deemed fruit of the poisonous tree should be admissible was not clearly answered by Swiss law or jurisprudence. ${ }^{333}$ Finally, in October 2007, the Supreme Court ruled on the issue. After considering the varying arguments by legal scholars, ${ }^{334}$ the Supreme Court held that whilst the admission of indirect evidence may undermine the rules of evidence, its exclusion would hinder the search for the truth. It went on to say that the most appropriate solution is to exclude indirect evidence, but only where it could not have been obtained without the initial, direct evidence. ${ }^{335}$ This ruling was subsequently codified in art. 141 (4) CPC.

On its face, the Supreme Court's holding was clear. However, the question of whether or not indirect evidence could have been obtained without the initial, illegally obtained, evidence introduces ambiguity. ${ }^{336}$ To make matters worse, in the 2007 ruling the Court emphasized the importance of balancing the relevant interests in determining whether or not to exclude fruit of the poisonous tree. ${ }^{337}$ Since the codification of the fruit of the poisonous tree doctrine in Article 141 Abs. 4 CPC, however, there is no longer any room to balance competing interests because the statute does not explicitly grant the courts discretion to do so. In such situations, the court has very little leeway in determining the mere factual question of whether the indirect evidence could have been obtained without the initial unlawfully procured evidence. $^{338}$

Since the 2007 decision, the Supreme Court has interpreted the newly adopted fruit of the poisonous tree doctrine quite narrowly, repeatedly arguing in favor of admitting evidence based on speculative and hypothetical clean path analyses. ${ }^{339} \mathrm{It}$ even went as far to state that the acquittal of an obviously guilty defendant under on the fruit of the poisonous tree doctrine would be "disturbing" ("stossend"). ${ }^{340}$ This argument is in stark contrast to the underlying rationale of safeguarding human rights by placing clear-cut limitations on law enforcement's search for the truth and the state's interest in obtaining convictions. If the impending acquittal of a guilty

\footnotetext{
${ }^{332}$ Häring, 2009 at 253.

${ }^{333}$ BGE 109 Ia 244, consid. 2.b.; BGE 132 IV 70, consid. 2.6.

${ }^{334}$ See the references in BGE 133 IV 329, consid. 4.5.

${ }^{335}$ BGE 133 IV 329, consid. 4.5.

${ }^{336}$ Also BGE 133 IV 329, consid. 3.3.1.

${ }^{337}$ BGE 138 IV 169, consid. 3.3.2.

${ }^{338} \mathrm{Gless} /$ Martin, 2015 at 169 et seq.

${ }^{339}$ BGE 133 IV 329, consid. 4.6; Ruckstuhl et al., 2011 at no. 569; Wohlers/Bläsi, 2015 at 167.

${ }^{340}$ BGE 133 IV 329, consid. 4.5.
} 
person is perceived as unacceptable and as a reason for admitting evidence, exclusionary rules become meaningless. Additionally, acquitting a defendant due to a lack of admissible evidence does not nullify the pursuit of the truth, but is a necessary consequence of setting boundaries and limitations in criminal proceedings. $^{341}$

After being criticized by a number of legal scholars, ${ }^{342}$ the Supreme Court redefined the hypothetical clean path analysis more clearly and held that the theoretical possibility that evidence was obtained legally is insufficient; rather, a strong probability that the indirect evidence would have been obtained without relying on the illegally gathered evidence is required. ${ }^{343}$ Notwithstanding this clarification, the Supreme Court still seems to be lenient in its decisions on what constitutes "a strong probability." ${ }^{344}$ Notably, in the same case where it clarified the clear path analysis, the Court subsequently admitted indirect evidence based on a less-than convincing hypothetical clean path. In that case, a drug trafficker passed the Swiss border in possession of drugs hidden in a fire extinguisher and the Swiss prosecution authorities had knowledge about his involvement due to an illegal wiretap in Slovenia. Consequently, the border patrol stopped him, searched his car, and located a large quantity of drugs. ${ }^{345}$ The Swiss Supreme Court held that the drugs were admissible because, despite the abolition of systematic border controls in the Schengen Area, the defendant was likely to be stopped and searched at the Swiss border because of his nervous demeanor. ${ }^{346}$

This holding is problematic because it is based upon hindsight analyses using all the facts, including the illegally obtained evidence. ${ }^{347}$ From this perspective it is very easy to construct a hypothetical clean path to admit the evidence in question, even if it is highly speculative. Therefore, some scholars correctly advocate for admitting indirect evidence only in cases where - from an ex ante point of viewits obtainment without the tainted direct evidence constitutes a "probability bordering on certainty". ${ }^{348}$ Although it is likely that such cases will be rare, ${ }^{349}$ it should be noted that the Swiss Supreme Court's jurisprudence is not entirely

\footnotetext{
${ }^{341}$ Vetterli, 2012 at 457.

${ }^{342}$ Gless, 2010 at 154 et seq.; Gless in Niggli et al., 2014 at art. 141 no. 97; Pieth, 2016 at 199 et seq.; Ruckstuhl et al., 2011 at no. 569 et seq.; Wohlers in Donatsch et. al, 2014 at art. 141 no. 15.

${ }^{343}$ BGE 138 IV 169, consid. 333.

${ }^{344}$ Gless, 2016 at 136; Wohlers/Bläsi, 2015 at 168, both with further references.

${ }^{345}$ BGE 138 IV 169, consid. 3.4.1. and 3.4.3.

${ }^{346}$ BGE 138 IV 169, consid. 3.4.3.; critical Vetterli, 2012 at 468; Wohlers/Bläsi, 2015 at 168. Another case where the SSC admitted indirect tainted evidence: BGer 6B_684/2012 of 15 May 2013, consid. 3.3.2.

${ }^{347}$ Häring, 2009 at 252 et seq.; Ruckstuhl et al., 2011 at no. 570; Wohlers/Bläsi, 2015 at 168.

${ }^{348}$ Gless, 2010 at 155, 159; Gless, 2012 at 141, 143; Häring, 2009 at 253; Pieth, 2016 at 199 with further references; Vetterli, 2012 at 467 et seq.; Wohlers in Donatsch et al., 2014 at art. 141 no. 15.

${ }^{349}$ Vetterli, 2012 at 467.
} 
one-sided. It excluded indirect evidence based on art. 141 (4) CPC in a case where the defendant confessed, but only after the prosecution authorities showed him an illegally recorded video containing information they could not have known otherwise. $^{350}$ However, upon closer inspection, the issue is not related to fruit of the poisonous tree because presentation of illegally obtained evidence constitutes deceptive police tactics and the obtained confession was required to be excluded directly under the terms of art. 141 (1) CPC. ${ }^{351}$

Overall, the case law of the Swiss Supreme Court illustrates how the effectiveness of exclusionary rules is completely dependent upon the local practice and jurisprudence. It should also be kept in mind, however, that the Swiss legislature chose not to establish a stricter fruit of the poisonous tree doctrine, ${ }^{352}$ and instead codified the Supreme Court's case law through art. 141 (4) CPC. ${ }^{353}$ Furthermore, the Supreme Court's narrow interpretation of the statute up until now is limited to cases where evidence was obtained by unauthorized searches or surveillance. It is thus unclear how it will decide if and when confronted with a case of torture or the use of improper compulsory measures. If the Court elects to strictly exclude evidence in such cases, defendants will be afforded comprehensive protection. However, even if it decides to apply the limited exclusionary rule of art. 141 (4) CPC, it is still unlikely that it will admit tainted evidence as freely as it has in the past.

\subsubsection{The Effect of International Human Rights Law}

It is the prevailing opinion that evidentiary rules in criminal procedure are the prerogative of the national legislature. As such, only a few (and rather vague) ${ }^{354}$ international guidelines on exclusionary rules exist. ${ }^{355}$ Nevertheless, international law and jurisprudence do still influence national evidentiary law and are of particular importance when defining concepts such as torture and inhuman treatment. ${ }^{356}$ Article 15 of the UNCAT implies the absolute exclusion of evidence obtained through torture and degrading treatment. ${ }^{357}$ The ECtHR has also set clear limitations on evidence taking in recent cases and has held that the admission of evidence obtained through torture is strictly prohibited as violative of art.

\footnotetext{
${ }^{350} \mathrm{BGE} 137$ I 218, consid. 2.4.2; see also the detailed analysis of this case in Vetterli, 2012 at 447 et seq.

${ }^{351}$ Vetterli, 2012 at 469.

${ }^{352} \mathrm{Also}$ the examples on admissible and inadmissible indirect evidence in Bundesblatt 2006 at 1184.

${ }^{353}$ See above 3.2.5.1.

${ }^{354}$ Gless in Niggli et al., 2014 at art. 139 no. 12.

${ }^{355}$ Gless in Niggli et al., 2014 at art. 141 no. 19.

${ }^{356}$ Gless in Niggli et al., 2014 at art. 140 no. 35; see above 3.2.2.

${ }^{357}$ Gless in Niggli et al., 2014 at art. 141 no. 15.
} 
3 ECHR. ${ }^{358}$ However, the ECtHR has not taken a similar path with respect to the exclusion of evidence gathered by inhuman treatment ${ }^{359}$ or indirect evidence acquired through torture. ${ }^{360}$ In these cases, the ECtHR appears to be more likely to exclude evidence where the offense in question constitutes a less serious, victimless crime, such as a drug offense. ${ }^{361}$ Additionally, according to the ECHR, the violation of rights ensuring a fair trial such as the right against self-incrimination ${ }^{362}$ may, but do not require, that the evidence in question be excluded. ${ }^{363}$ On the contrary, the ECtHR generally limits itself to examine "whether the proceedings as a whole, including the way in which the evidence was obtained, were fair" ${ }^{364}$ and if they conformed with art. 6 ECHR. The result is that many decisions by the ECtHR are not strictly followed by the national courts, ${ }^{365}$ thereby weakening the rights enshrined in the ECHR.

\section{Statistics}

There is, unfortunately, very little empirical data evaluating the importance of fair trial principles in Swiss criminal procedure. ${ }^{366}$ This is particularly the case with regard to the practical impact of exclusionary rules. That said, a trial observation project was recently finished and included the evaluation of criminal proceedings in first instance courts in four Swiss cantons over the course of two years. The project investigated how often defense rights were asserted and how the courts dealt with those requests. ${ }^{367}$ The study was based on the observation of 439 randomly cho$\operatorname{sen}^{368}$ court hearings and subsequent interviews with the parties involved

\footnotetext{
${ }^{358}$ For example, ECtHR, Gäfgen v. Germany, case no. 22978/05, Judgment (Grand Chamber) of 1 June 2010, $\S 131$ et seq. and 167; Gless, in Niggli et al., 2014 at art. 141 no. 22; Thommen/ Samadi, 2016 at 76.

${ }^{359} \mathrm{ECtHR}$, Jalloh v. Germany, case no. 54810/00, Judgment (Grand Chamber) of 11 July 2006, § 83 and 103 et seq.; Thommen/Samadi, 2016 at 77.

${ }^{360}$ ECtHR, Gäfgen v. Germany, case no. 22978/05, Judgment (Grand Chamber) of 1 June 2010, § 169 et seq.; also Gless in Niggli et al., 2014 at art. 140 no. 14 with further references.

${ }^{361}$ Oberholzer, 2012 at no. 700 et seq.

${ }^{362}$ See Macula, 2016 at 28 et seq., 56 et seq.; Vest/Eicker, 2005 at 886.

${ }^{363}$ Thommen/Samadi, 2016 at 77 et seq. with further references.

${ }^{364}$ See, among others, ECtHR, Bykov v. Russia, case no. 4378/02, Judgment (Grand Chamber) of 10 March 2009, § 89 with further references; ECtHR, Schenk v. Switzerland, case no. 10862/84, Judgment of 12 July $1988, \S 46$.

${ }^{365}$ Gless in Niggli et al., 2014 at art. 139 no. 12. As to the problem of the reception of Strasbourg case law on criminal evidence, see also Jackson/Summers, 2013 at 114 et seq.

${ }^{366}$ Summer/Studer, 2016 at 45 et seq.

${ }^{367}$ Summer/Studer, 2016 at 46.

${ }^{368}$ Summer/Studer, 2016 at 54.
} 
(defendant, prosecution, defense counsel). ${ }^{369}$ During the project, infringements on the right to a fair trial were qualified as initiated by a party to the proceedings, initiated by the court, or exclusively observed by the project members. ${ }^{370}$ The results of this study showed that, out of 714 infringements on the right to a fair trial (initiated or observed), only 35 were related to infringements on the right against self-incrimination. Furthermore, 15 infringements were related to otherwise illegally obtained evidence that do not fall under the scope of art. 6 (1) ECHR (evidence obtained in violation of art. 3 or art. 8 ECHR). However, the infringement on rights related to other aspects of a fair trial, including the right to summon and question witnesses (113), the right to have an interpreter (104), the presumption of innocence (102) and the right to a speedy trial (98), were much more often discussed and observed. ${ }^{371}$ Furthermore, the project found that most infringements on defendant rights observed by the project members did not lead to a complaint by the defendant or the defense counsel. ${ }^{372}$ Although this data does not provide a basis for a definitive assessment, it does indicate that, in the end, the exclusion of evidence obtained in breach of the right against self-incrimination and of the prohibition on torture is of less practical importance in Switzerland than would be suggested by the level of importance given to this issue in literature.

\section{Conclusion}

Swiss exclusionary rules look very promising as law on the books. In 2011, a far-reaching, concise statute established what appeared to be clear-cut guidelines to safeguard individual rights in criminal proceedings in Switzerland. The harmonization of the law and the clarification of exclusionary rules in a few specific cases has triggered a lively discussion among courts, defense lawyers, academics, and occasionally even the public.

Practically speaking, however, the Swiss statutes face several hurdles impairing the efficiency of exclusionary rules in the Swiss criminal justice system. First, art. $141 \mathrm{CPC}$ leaves open several important questions, including means of enforcing exclusionary rules and the admissibility of indirect evidence obtained following a violation of art. 141 (1) CPC. Furthermore, the wording of art. $141 \mathrm{CPC}$ is vague,

\footnotetext{
${ }^{369}$ Summer/Studer, 2016 at 51 et seq.

${ }^{370}$ Summer/Studer, 2016 at 60.

${ }^{371}$ The charts in Summer/Studer, 2016 at 60 et seq. The numbers in brackets indicate the numbers of incidents brought up or observed.

${ }^{372}$ Such omission might be due to lack of information on the side of the defence, especially if a defendant is not represented by a lawyer. Furthermore, formally claiming a violation of rights might not lead to a clear advantage and the defendant may even be afraid to rebuff the judges by claiming the authorities violated procedural rights. Some rights might even be law on the books only, poorly implemented in practice, which might eventually lead to a largely accepted "custom" of non-compliance. Summers/Studer, 2016 at 62 et seq. and 72.
} 
including terms such as "serious offence," and "essential [...] to secure a conviction." Statutory concepts are also unclear at times, such as the distinction between "regulations on admissibility" and "administrative regulations," as well as the hypothetical clean path analysis. These ambiguities confer a great deal of discretion upon the courts. Finally, art. 141 (2) CPC allows, under certain circumstances, the use of evidence obtained in violation of regulations on admissibility. Such regulations are of considerable importance for safeguarding individual rights and limited exclusion of evidence obtained in their violation does not provide effective protection of those rights.

The problems of art. $141 \mathrm{CPC}$ stem from the fact that the statute is essentially a codification of the Supreme Court's case law. Accordingly, issues continue with the Court closing the legal loopholes and defining the vague legal terms through a longstanding and heavy emphasis on the importance of establishing the truth and prosecuting crimes. Thus, on the one hand, the Supreme Court is quite restrictive in its classification of provisions as regulations on admissibility. On the other hand, it is very quick to define an offense as "serious" or to construct a speculative (and hypothetical) clean path. The case law assigning authority to decide the admissibility of evidence to the same judge who later determines the guilt or innocence of a defendant further reduces the efficacy of art. 141 CPC.

As a result, the initially promising exclusionary rules in the new Swiss CPC lose a great deal of practical impact in their ability to safeguard individual rights in criminal proceedings. Article 141 CPC and the Supreme Court's case law are also criticized by legal scholars. Nevertheless, exclusionary rules are the only possible way to ensure that an irreversible violation of the law does not pose any further detriment to a defendant. Other measures, such as disciplinary or criminal proceedings against a guilty law enforcement official, may be useful as supporting measures, but are not viable alternatives to exclusionary rules. As such, it is particularly important to ensure effective exclusionary rules and to limit the amount of judicial interpretation that can be used to narrow their scope. To achieve this, it is important that the legislature drafts clear statutes. With respect to art. 141 CPC, clearer definitions of vague terms, a critical assessment of the balancing approach in cases of violations of regulations of admissibility, as well as the explicit and strict exclusion of indirect evidence stemming from evidence obtained through torture and other improper compulsion would be helpful. Moreover, a clear stipulation addressing means of enforcement by an authority other than the judge of fact would be preferable to ensure objectivity. Unfortunately, the recent reform efforts regarding exclusionary rules are limited to an amendment of art. 141 (4) CPC, extending its scope of application explicitly to "evidence inadmissible under paragraph 1 and 2 " of art. 141 CPC. ${ }^{373}$

\footnotetext{
${ }^{373}$ See art. 141 (4) of the preliminary draft regarding a reform of the CPC submitted by the Swiss Federal Council in December 2017, available online at <https://www.bj.admin.ch/dam/data/bj/ sicherheit/gesetzgebung/aenderungstpo/vorentw-d.pdf>, accessed 22 November 2018.
} 
Pursuant to the wording of this preliminary draft, a violation of art. 140 (1) CPC, however, would not lead to the strict but to a rather limited exclusion of indirect evidence: Such evidence would remain admissible if it could have been obtained without the direct evidence. It is unclear whether the Federal Counsil intended this consequence or whether he just had in mind to clarify that a violation of art. 141 (1) $\mathrm{CPC}$ should also entail the exclusion of indirect evidence. ${ }^{374}$

\section{References}

\section{Books}

Brun, Marcel, Staatsanwaltschaft und Fehlurteilsrisiken im Vorverfahren, Diss. Basel 2015. [Brun, 2015]

Fornito, Roberto, Beweisverbote im Schweizerischen Strafprozess, Diss. St. Gallen 2000. [Fornito, 2000]

Donatsch, Andreas/Schwarzenegger, Christian/Wohlers, Wolfgang, Strafprozessrecht $2^{\text {nd }}$ ed., Zürich 2014. [Donatsch/Schwarzenegger/Wohlers, 2014]

Macula, Laura, Verwaltungs(aufsichts)rechtliche Mitwirkungspflichten und strafprozessuale Selbstbelastungsfreiheit, Zürich 2016. [Macula, 2016]

Oberholzer, Niklaus, Grundzüge des Strafprozessrechts $3^{\text {rd }}$ ed., Bern 2012. [Oberholzer, 2012]

Pieth, Mark, Schweizerisches Strafprozessrecht. Grundriss für Studium und Praxis $3^{\text {rd }}$ ed., Basel 2016. [Pieth, 2016]

Ruckstuhl, Niklaus/Dittmann, Volker/Arnold, Jörg, Strafprozessrecht unter Einschluss der forensischen Psychiatrie und Rechtsmedizin sowie des kriminaltechnischen und naturwissenschaftlichen Gutachtens, Zürich 2011. [Ruckstuhl et al., 2011]

Schlauri, Regula, Das Verbot des Selbstbelastungszwangs im Strafverfahren: Konkretisierung eines Grundrechts durch Rechtsvergleichung, Zürich 2003. [Schlauri, 2003]

Schmid, Niklaus, Handbuch des schweizerischen Strafprozessrechts $3^{\text {rd }}$ ed., Zürich/St. Gallen 2017. [Schmid, 2017]

Thommen, Marc, Kurzer Prozess - fairer Prozess? Strafbefehls- und abgekürzte Verfahren zwischen Effizienz und Gerechtigkeit, Habil. Bern 2013. [Thommen, 2013]

Groner, Roger, Beweisrecht. Beweise und Beweisverfahren im Zivil- und Strafrecht, Bern 2011. [Groner, 2011]

\section{Journal Articles}

Bürge, Lukas, 'Die Unverwertbarkeit von Beweisen - ein Überblick', (2017) Anwaltsrevue, 32224. [Bürge, 2017]

Donatsch, Andreas/Cavegn, Claudine, 'Ausgewählte Fragen zum Beweisrecht nach der schweizerischen Strafprozessordnung’, (2008) 126 Schweizerische Zeitschrift für Strafrecht, 158-73. [Donatsch/Cavegn, 2008]

\footnotetext{
${ }^{374}$ See Swiss Federal Council, Erläuternder Bericht zur Änderung der Strafprozessordnung of December 2017, at 25, available online at <https://www.bj.admin.ch/dam/data/bj/sicherheit/ gesetzgebung/aenderungstpo/vn-ber-d.pdf $>$, accessed 22 November 2018.
} 
Geisselhardt, Angela, 'Zuständigkeit bei Beweisverboten im Strafverfahren', (2014) 7 forumpoenale, 300-06. [Geisselhardt, 2014]

Gless, Sabine, 'Beweisverbote und Fernwirkung', (2010) 128 Schweizerische Zeitschrift für Strafrecht, 146-60. [Gless, 2010]

Gless, Sabine, 'Urteilsbesprechung Obergericht Zürich, III. Strafkammer, Beschluss vom 24. April 2013 i.S. X. gegen Staatsanwaltschaft Zürich-Sihl - UH120368', (2013) 6 forumpoenale, 343 47. [Gless, 2013]

Häring, Daniel, 'Verwertbarkeit rechtswidrig erlangter Beweise gemäss Schweizerischer Strafprozessordnung - alte Zöpfe oder substanzielle Neuerungen?', (2009) 127 Schweizerische Zeitschrift für Strafrecht, 225-57. [Häring, 2009]

Hersch, Gabriel, 'Die Verwertbarkeit rechtswidrig erlangter Beweise gemäss Art. 141 Abs. 2 StPO: Kodifizierung der Rechtsprechung des Bundesgerichts?', (2012) 130 Schweizerische Zeitschrift für Strafrecht, 352-72. [Hersch, 2012]

Jackson, John/Summers, Sarah, 'Confrontation with Strasbourg: UK and Swiss approaches to criminal evidence', (2013) 60 Criminal Law Review, 114-30. [Jackson/Summers, 2013]

Keller, Andreas J., 'Die neue schweizerische StPO: Formalisierung und Effizienz - bleibt die materielle Wahrheit auf der Strecke?', (2011) 129 Schweizerische Zeitschrift für Strafrecht, 229-57. [Keller, 2011]

Riklin, Franz, 'Strafbefehlsverfahren - Effizienz auf Kosten der Rechtsstaatlichkeit?', (2016) 152 Zeitschrift des Bernischen Juristenvereins, 475-99. [Riklin, 2016]

Ruckstuhl, Niklaus, 'Rechtswidrige Beweise erlaubt', (2006) 23 plädoyer, 15-22. [Ruckstuhl, 2006]

Schweizer, Rainer J., 'Die Aufsicht über die Staatsanwaltschaften', (2013) 26 Aktuelle Juristische Praxis, 1378-89. [Schweizer, 2013]

Summers, Sarah/Studer, David, 'Fairness im Strafverfahren? Eine empirische Untersuchung', (2016) 134 Schweizerische Zeitschrift für Strafrecht, 45-72. [Summers/Studer, 2016]

Thommen, Marc/Samadi, Mojan, 'The Bigger the Crime, the Smaller the Chance of a Fair Trial? Evidence Exclusion in Serious Crime Cases Under Swiss, Dutch and European Human Rights Law', (2016) 24 European Journal of Crime, Criminal Law and Criminal Justice, 65-86. [Thommen/Samadi, 2016]

Trechsel, Stefan, 'Gerechtigkeit im Fehlurteil' (2000) 118 Schweizerische Zeitschrift für Strafrecht, 1-18. [Trechsel, 2000]

Vest, Hans/Eicker, Andreas, 'Aussageverweigerungsrecht und Beweisverwertungsverbot. Zugleich eine Besprechung von BGE 130 I 126', (2005) 14 Aktuelle Juristische Praxis, 883-92. [Vest/Eicker, 2005]

Vest, Hans/Höhener, Andrea, 'Beweisverwertungsverbote - quo vadis Bundesgericht?', (2009) 127 Schweizerische Zeitschrift für Strafrecht, 95-108. [Vest/Höhener, 2009]

Vetterli, Luzia, 'Kehrtwende in der bundesgerichtlichen Praxis zu den Verwertungsverboten', (2012) 130 Schweizerische Zeitschrift für Strafrecht, 447-70. [Vetterli, 2012]

Wohlers, Wolfgang/Bläsi, Linda, 'Dogmatik und praktische Relevanz der Beweisverwertungsverbote im Strafprozessrecht der Schweiz' (2015) 134 recht, 158-75. [Wohlers/Bläsi, 2015]

\section{Contributions to Edited Volumes and Annotated Law}

Demko, Daniela, 'Das „,(Un-)Gerechte“ am Fair-Trial-Grundsatz nach Art. 6 Abs. 1 EMRK im Strafverfahren', in: Niggli, Marcel Alexander/Hurtado Pozo, José/Queloz, Nicolas (eds.), Festschrift für Franz, Riklin. Zur Emeritierung und zugleich dem 67. Geburtstag, Zürich 2007, 351-64. [Demko, 2007]

Donatsch, Andreas/Hansjakob, Thomas/Lieber, Viktor (eds.), Kommentar zur Schweizerischen Strafprozessordnung (StPO) $2^{\text {nd }}$ ed., Zürich 2014. [Author in Donatsch et al., 2014] 
Gilliéron, Gwlady/Killias, Martin, 'Strafbefehl und Justizirrtum: Franz Riklin hatte Recht!', in: Niggli, Marcel Alexander/Hurtado Pozo, José/Queloz, Nicolas (eds.), Festschrift für Franz Riklin. Zur Emeritierung und zugleich dem 67. Geburtstag, Zürich 2007, 379-98. [Gilliéron/ Killias, 2007]

Gless, Sabine, 'Heiligt der Zweck die Mittel? Beweisverbote im vereinheitlichten eidgenössischen Strafprozess', in: Niggli, Marcel Alexander/Pozo, José Hurtado/Queloz, Nicolas (eds.), Festschrift für Franz Riklin. Zur Emeritierung und zugleich dem 67. Geburtstag, Zürich 2007, 399-14. [Gless, 2007]

Gless, Sabine, 'Verwertungsverbote im Schweizer Strafprozess', in: Degener, Wilhelm/ Heghmanns, Michael (eds.), Festschrift für Friedrich Dencker zum 70. Geburtstag, Tübingen 2012, 135-45. [Gless, 2012]

Gless Sabine/Martin, Jeannine, 'Water Always Finds Its Way - Discretion and the Concept of Exclusionary Rules in the Swiss Criminal Procedure Code', in: Caianiello, Michele/Hodgson, Jacqueline S. (eds.), Discretionary Criminal Justice in a Comparative Context, Durham, North Carolina 2015, 159-84. [Gless/Martin, 2015]

Gless, Sabine, 'Gesetzliche Regelung von Beweisverwertungsverboten - die Schweiz als Vorreiter?', in: Gropp, Walter/Hecker, Bernd/Kreuzer, Arthur/Ringelmann, Christoph/ Witteck, Lars/Wolfslast, Gabriele (eds.), Strafrecht als ultima ratio. Giessener Gedächtnisschrift für Günter Heine, Tübingen 2016, 127-41. [Gless, 2016]

Niggli, Marcel Alexander/Heer, Marianne/Wiprächtiger, Hans (eds.), Basler Kommentar. Schweizerische Strafprozessordnung/Jugendstrafprozessordnung (StPO/JStPO) $2^{\text {nd }}$ ed., Basel 2014. [Author in Niggli et al., 2014]

Wohlers, Wolfgang, 'Verwertungs-, Verwendungs- und/oder Belastungsverbote - die Rechtsfolgenseite der Lehre von den Beweisverwertungsverboten', in: Herzog, Felix/ Schlothauer, Reinhold/Wohlers, Wolfgang (eds.), Rechtsstaatlicher Strafprozess und Bürgerrechte. Gedächtnisschrift für Edda Weßlau, Berlin 2016, 427-44. [Wohlers, 2016]

\section{Reports, Legislative History}

Swiss Federal Council, Erläuternder Bericht zur Änderung der Strafprozessordnung of December $2017<$ <ttps://www.bj.admin.ch/dam/data/bj/sicherheit/gesetzgebung/aenderungstpo/vn-ber-d. pdf>, accessed 22 November 2018.

Swiss Federal Council, Vorentwurf zur Änderung der Strafprozessordnung of December 2017 $<$ https://www.bj.admin.ch/dam/data/bj/sicherheit/gesetzgebung/aenderungstpo/vorentw-d.pdf>, accessed 22 November 2018.

Swiss Federal Department of Justice and Police, 'Examen du septième rapport périodique de la Suisse par le Comité contre la torture. Prise de position de la Suisse suite à l'adoption des observations finales par le CAT, le 13 août 2015', (6 July 2016). [CAT Report, 2016] <https:// www.google.com/url?sa=t\&rct=j\&q=\&esrc=s\&source=web\&cd=4\&ved=2ahUKEwiCm7Wj2 4bgAhVKLVAKHcspApcQFjADegQIABAB\&url=https\%3A\%2F\%2Ftbinternet.ohchr.org\%2 FTreaties\%2FCAT\%2FShared\%2520Documents\%2FCHE\%2FINT_CAT_FCO_CHE_22382 _F.pdf\&usg=AOvVaw1yCr3fN0Na3Tbo9L4amFYA>, accessed 22 November 2018.

Swiss Centre of Expertise in Human Rights (SCHR), Künzli, Jörg/Sturm, Evelyne/Veerakatty, Vijitha, 'Rechtsschutz gegen polizeiliche Übergriffe. Eine Darstellung der Beschwerdemechanismen in der Schweiz', (21 February 2014). [Künzli et al., 2014] <http:// www.skmr.ch/de/themenbereiche/justiz/publikationen/missbraeuchliche-polizeigewalt.html? zur $=106>$, accessed 22 November 2018.

Swiss Federal Council, Botschaft zur Vereinheitlichung des Strafprozessrechts of 21 December 2005, 05.092, Bundesblatt no. 6 (2006) 1085. [Bundesblatt, 2006] <https://www.admin.ch/opc/ de/federal-gazette/2006/index_5.html>, accessed 22 November 2018. 
Swiss National Council, Official Bulletin of the National Council, Summer Session 2007. [Official Bulletin of the National Council, Summer Session 2007] <https://www.parlament.ch/en/ ratsbetrieb/amtliches-bulletin>, accessed 22 November 2018.

Council of States, Official Bulletin of Council of States, Winter Session 2006. [Official Bulletin of Council of States, Winter Session 2006] <https://www.parlament.ch/centers/documents/de/SR 06_12.pdf>, accessed 22 November 2018.

Laura Macula holds a Master's degree in law (summa cum laude). Her master's thesis discusses possible conflicts between the right against self-incrimination and information duties under the Swiss financial market regulation. It was published in 2016. Her doctoral theses analyzes exclusionary rules from a comparative perspective with a particular focus on the exclusion of exonerating evidence.

Open Access This chapter is licensed under the terms of the Creative Commons Attribution 4.0 International License (http://creativecommons.org/licenses/by/4.0/), which permits use, sharing, adaptation, distribution and reproduction in any medium or format, as long as you give appropriate credit to the original author(s) and the source, provide a link to the Creative Commons license and indicate if changes were made.

The images or other third party material in this chapter are included in the chapter's Creative Commons license, unless indicated otherwise in a credit line to the material. If material is not included in the chapter's Creative Commons license and your intended use is not permitted by statutory regulation or exceeds the permitted use, you will need to obtain permission directly from the copyright holder.

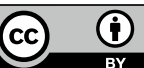

